J. Dairy Sci. 98:6631-6650

http://dx.doi.org/10.3168/jds.2015-9683

(C) American Dairy Science Association ${ }^{\circledR}, 2015$.

\title{
Invited review: Inflammation during the transition to lactation: New adventures with an old flame
}

\author{
B. J. Bradford, ${ }^{1}$ K. Yuan, J. K. Farney, L. K. Mamedova, and A. J. Carpenter \\ Department of Animal Sciences and Industry, Kansas State University, Manhattan 66506
}

\begin{abstract}
For dairy cattle, the first several weeks of lactation represent the highest-risk period in their lives after their own neonatal period. Although more than 50\% of cows during this period are estimated to suffer from at least one subclinical disorder, the complicated admixture of normal adaptations to lactation, infectious challenges, and metabolic disorders has made it difficult to determine which physiological processes are adaptive and which are pathological during this time. Subacute inflammation, a condition that has been well documented in obesity, has been a subject of great interest among dairy cattle physiologists in the past decade. Many studies have now clearly shown that essentially all cows experience some degree of systemic inflammation in the several days after parturition. The magnitude and likely persistence of the inflammatory state varies widely among cows, and several studies have linked the degree of postpartum inflammation to increased disease risk and decreased whole-lactation milk production. In addition to these associations, enhancing postpartum inflammation with repeated subacute administration of cytokines has impaired productivity and markers of health, whereas targeted use of nonsteroidal anti-inflammatory drugs during this window of time has enhanced whole-lactation productivity in several studies. Despite these findings, many questions remain about postpartum inflammation, including which organs are key initiators of this state and what signaling molecules are responsible for systemic and tissue-specific inflammatory states. Continued in vivo work should help clarify the degree to which mild postpartum inflammation is adaptive and whether the targeted use of anti-inflammatory drugs or nutrients can improve the health and productivity of dairy cows.
\end{abstract}

Received April 8, 2015.

Accepted June 6, 2015.

${ }^{1}$ Corresponding author: bbradfor@ksu.edu
Key words: postpartum inflammation, transition, dairy cow, health and productivity

\section{INTRODUCTION}

The onset of lactation is a critical time for any dam. Lactogenesis, uterine involution, and the accompanying changes in endocrine and metabolic states create a unique set of adaptive challenges, and these challenges are particularly dramatic for the dairy cow. It is not uncommon for the 2 short weeks after parturition to account for $50 \%$ of morbidity on a dairy farm, and disease-related culling in early lactation remains a major problem from both economic and animal welfare perspectives.

In his influential review article, Drackley (1999) argued that the biology underlying the transition to lactation was the "final frontier" in our understanding of the dairy cow. This prescient assertion remains true today; although the field has made progress in alleviating clinical hypocalcemia, most other disorders common during the transition period remain as prevalent now as they were 20 yr ago (Goff, 2006; USDA, 2009). Rather than attempting to define the state of transition cow biology as a whole, the purpose of this review is to focus on inflammation as an emerging aspect of transition cow biology. Our goal is to summarize the current understanding of this phenomenon, how it contributes to physiology and pathology in early lactation, and to highlight critical questions that remain unanswered.

\section{THE MOLECULAR KINDLING FOR INFLAMMATION}

Inflammation is an evolutionarily conserved response underlying many physiological and pathological processes. In response to stimuli associated with infection and tissue injury, components of innate and adaptive immunity initiate coordinated responses and trigger inflammation (Medzhitov, 2008). Ideally, inflammation helps the body adapt to and overcome adverse stimuli, with the goal of restoring homeostasis. As inflammation has received increasing attention among biologists in recent decades, 2 somewhat distinct processes have 
been identified that we will refer to as acute and subacute inflammation.

\section{Acute Inflammation}

Classic signs of inflammation are redness, swelling, heat, and pain. In response to acute inflammatory stimuli, the body increases the expression and release of inflammatory mediators including cytokines, chemokines, adhesion molecules, eicosanoids, and complement proteins (Newton and Dixit, 2012). These molecules form complex regulatory networks to promote increased blood flow to the infected tissue, immune cell infiltration and activation, and systemic responses, including increased body temperature, increased heart rate, and decreased appetite (Dantzer and Kelley, 2007). Cyto-

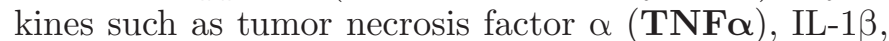
and IL-6 are produced by many cell types, especially macrophages and mast cells. They play important roles in the inflammatory response by activating leukocytes and endothelial cells as well as triggering the acutephase response (Bannerman et al., 2009).

Much inflammation research has naturally focused on immune cells. However, most cell types across organ systems express receptors for inflammatory cytokines, and these parenchymal cells mediate many of the systemic responses to immune activation. For example, cytokines released by immune cells during infection travel through the bloodstream and stimulate prostaglandin $\mathrm{E}_{2}$ production in endothelial cells, which in turn acts on neurons in the preoptic area of the brain to increase the set point for core body temperature (Nakamura, 2011). This mechanism for fever induction, which involves cross-talk between immune and nonimmune cells of various lineages, is similar to many inflammatory response cascades.

One key secondary response to inflammation is the acute-phase response. Produced in greatest quantity by the liver, acute-phase proteins include haptoglobin, ceruloplasmin, serum amyloid A, and C-reactive protein. Proteins involved in the acute-phase response are generally found in very low abundance in the bloodstream, but their concentrations are greatly elevated during systemic inflammation. At the same time, other proteins typically secreted by the liver (e.g., albumin) decline in concentration and therefore are sometimes known as negative acute-phase reactants. The importance of some acute-phase proteins in response to infection is somewhat unclear, but they have gained widespread acceptance as inflammation markers (Ceciliani et al., 2012).

The most costly inflammatory disease in dairy cows is mastitis, which commonly results from microbial infec- tion of the mammary gland (Bannerman et al., 2009). If the infection is caused by gram-negative bacteria, LPS released from the bacterial outer membrane is the main pathogen component initiating inflammatory responses (Hogan and Smith, 2003). The subsequent production of pro-inflammatory cytokines induced by LPS (Schukken et al., 2011) elicits the migration of leukocytes (primarily neutrophils) to the site of infection. After they reach the afflicted tissue, neutrophils become activated and release the toxic contents of their granules, including reactive oxygen species, reactive nitrogen species, and proteases. These potent effectors are important in facilitating pathogen clearance, but they may also promote the breakdown of the blood-milk barrier and induce mammary epithelial tissue damage (Schukken et al., 2011). The reduced number and activity of secretory cells consequently contributes to decreased milk synthesis and secretion (Ballou, 2012). In addition to mastitis, uterine infections are common in early lactation. Essentially all cows have bacterial contamination of the uterus within 3 wk after calving, and the majority have at least one form of pathology of the reproductive tract (LeBlanc et al., 2011).

Although a controlled inflammatory process normally leads to recovery from infection, uncontrolled (e.g., sepsis) or chronic inflammatory conditions can be detrimental. Therefore, in an ideal acute inflammatory response, a rapid resolution phase following elimination of the infectious agents is necessary (Medzhitov, 2008). Important resolving signals include anti-inflammatory cytokines such as IL-10 (Fiorentino et al., 1991; Banchereau et al., 2012) and n-3 (omega-3) fatty acid derivatives such as resolvins and protectins (Spite et al., 2014).

\section{Subacute Inflammation}

Although dramatic elevation of inflammatory signals can induce a cytokine storm and even tissue damage, subacute inflammation causes mild increases in inflammatory mediators that contribute to chronic and progressive changes in tissue function. Low-grade chronic inflammation occurs in a wide variety of diseases, including obesity and type 2 diabetes in humans. The chronic inflammation associated with metabolic disorders is also referred to as metabolic inflammation (Hotamisligil, 2006). Unlike classical inflammation that is induced by infection and injury and then resolves, subacute inflammation is associated with tissue malfunction. In obesity, for example, subacute inflammation is initiated by excess nutrients in metabolic tissues (Gregor and Hotamisligil, 2011). This response eventually activates multiple types of immune cells and leads 


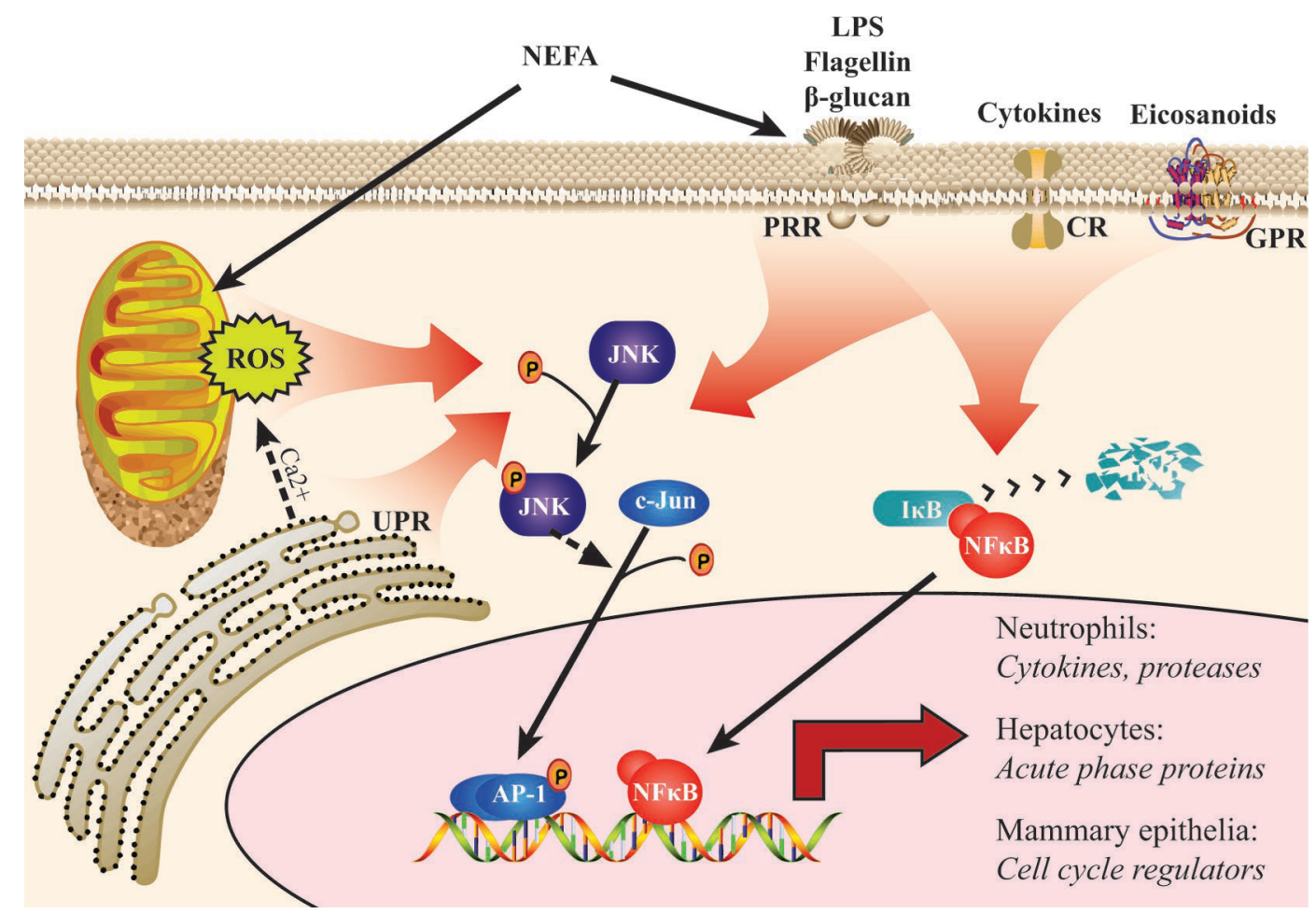

Figure 1. Multiple signals converge to drive inflammatory transcription. A variety of extracellular metabolites, hormones, and microbial products trigger inflammatory responses. Nonesterified fatty acids can promote reactive oxygen species (ROS) production associated with mitochondrial metabolism and can activate pattern recognition receptors (PRR). Molecules associated with pathogens, including LPS, flagellin, and $\beta$-glucan, are potent triggers for PRR activation. Cytokine receptors (CR) and certain G-protein receptors (GPR) mediate the effects of inflammatory cytokines and eicosanoids, respectively. The uncoupled protein response (UPR) associated with endoplasmic reticulum stress can contribute to inflammation both directly and indirectly, via calcium-mediated promotion of ROS escape from mitochondria. These signals are integrated largely through the activation of 2 key transcription factors: activator protein 1 (AP-1, also known as Jun) and nuclear factor kappalight-chain-enhancer of activated B cells (NF- $\kappa B$ ). Activation of AP-1 occurs when c-Jun NH2-terminal kinase (JNK) is activated by upstream kinases, resulting in phosphorylation (P) of c-Jun. Phosphorylated c-Jun translocates to the nucleus and forms a heterodimer with c-Fos to create the AP-1 transcription factor. Activation of NF- $\kappa \mathrm{B}$ occurs when upstream kinases phosphorylate inhibitor of kappa B (I $k \mathrm{~B}$ ), leading to its degradation and releasing NF- $\mathrm{kB}$ for translocation to the nucleus. Inflammatory transcriptional programs differ by organ and cell type, but several key target gene families are denoted as examples. Color version available online.

to an unresolved tissue inflammatory response, which often disrupts metabolism by mechanisms such as inhibiting insulin action (Gregor and Hotamisligil, 2011).

\section{Common Signaling Mechanisms}

Although acute and subacute inflammation induce different responses, they share most signaling pathways. In fact, the line between "hot" and "cold" inflammation, as some have referred to the different forms (Calay and Hotamisligil, 2013), is most often defined by the magnitude of the signals generated and the relative sensitivity of various physiological responses, rather than by distinct signaling mechanisms.

A key aspect of inflammatory signaling is its integrative nature. Many studies have documented additive or even synergistic effects of diverse pro-inflammatory signals when administered to cells or animals simultaneously (Sonti et al., 1996; Yoshioka et al., 2002).
Through the use of cell culture and genetically altered mouse models, several important endocrine, paracrine, and autocrine inflammatory signals have been identified, with a relatively solid understanding of the downstream signal transduction pathways that result in activation of inflammatory transcription programs (Figure 1).

Among the most ancient components of the immune system are pattern recognition receptors (PRR) that bind to chemicals associated with broad classes of pathogens (Takeuchi and Akira, 2010); these compounds are referred to as pathogen-associated molecular patterns. The PRR include toll-like receptors (TLR), C-lectin receptors (activated by fungal molecules), and nucleotide-binding oligomerization domain (NOD)-like receptors (activated by intracellular bacteria). Although these receptors have been characterized by their response to pathogen-associated molecular patterns, some members are promiscuous receptors that can be 
activated by ligands not affiliated with pathogens at all. Notably, physiologically relevant ligands of TLR4 (commonly referred to as the LPS receptor) include saturated fatty acids (Mamedova et al., 2013), which are greatly elevated in early lactation.

Pro-inflammatory cytokines and eicosanoids are critical mediators of the inflammatory escalation carried out by the immune system upon recognition of infectious signals (Tisoncik et al., 2012; Hardwick et al., 2013). Although immune cells are often involved in release of these signals, receptors for cytokines and eicosanoids are broadly expressed, allowing these compounds to influence nearly all tissues (Elsasser et al., 2008; Garlanda et al., 2013).

Cytokine receptors, G-protein-coupled eicosanoid receptors, and PRR are heterogeneous in structure and in the ligands to which they respond, but the signaling cascades downstream of these receptors nevertheless converge (Gregor and Hotamisligil, 2011; Ji et al., 2012). Signals are integrated through kinase cascades that affect the activity of inhibitor of kappa kinase (IKK) isoforms. Activation of IKK, in turn, triggers phosphorylation and degradation of inhibitor of kappa $\mathrm{B}(\mathbf{I} \boldsymbol{k B})$ isoforms, allowing the subsequent translocation of nuclear factor $(\mathbf{N F})-\kappa B$ into the nucleus to trigger inflammatory transcriptional responses (Hoffmann and Baltimore, 2006).

Another central inflammatory signaling cascade is mediated by c-Jun $\mathrm{NH}_{2}$-terminal kinase (JNK). A member of the mitogen-activated protein kinase family with a variety of downstream targets, JNK is most commonly associated with the transcription factor activator protein 1 (Vallerie and Hotamisligil, 2010). Activation of JNK signaling can occur in a variety of ways. Among them, endoplasmic reticulum (ER) stress and oxidative stress are likely to be important in transition dairy cows. Exposure to high concentrations of fatty acids, especially saturated fatty acids, can disrupt ER membranes and cause a stress response, at least in nonruminant cells (Wei et al., 2009; Mamedova et al., 2013). Disrupted ER function results in several problems, including release of stored calcium from the organelle and impaired protein folding. Protein misfolding triggers the aptly named unfolded protein response (UPR), which activates signaling cascades that are tightly interwoven with a variety of inflammatory pathways, including JNK (Darling and Cook, 2014). The calcium released from stressed ER contributes to oxidative stress, another problem associated with excessive lipid burden (Wei et al., 2009). Although some release of reactive oxygen species (ROS) by mitochondria is normal, disruptions in mitochondrial membranes, along with increased mitochondrial lipid flux, can greatly increase cytoplasmic ROS concentrations (Begriche et al., 2006). Elevated ROS, in turn, can activate JNK signaling (Imoto et al., 2006). The role of ER stress and the UPR in transition cow metabolic disorders was reviewed recently by Ringseis and colleagues (2015), and readers are directed to that paper for a more in-depth discussion of this complex area.

A final layer of integration can occur between transcription factors at adjacent binding sites on promoter regions; such integration can lead to a dramatic induction of transcriptional responses (Glass and Saijo, 2010). Cell-specific responses to integrated inflammatory signaling are extremely diverse and contribute to both normal physiology and pathological conditions (Baker et al., 2011; Garlanda et al., 2013).

It should be noted that inflammatory stimuli interact with a much broader set of signaling pathways than those shown in Figure 1. Inflammatory signals can interact with metabolic, translational, and cell cycle regulatory molecules independent of JNK and NF- $\kappa \mathrm{B}$. Furthermore, recent research suggests that acute and subacute levels of inflammatory stimuli may induce some distinct inflammatory signals. In contrast to high-dose LPS that induced a robust and transient expression of proinflammatory mediators in macrophages by activating the classical NF- $\kappa \mathrm{B}$ pathway, low-dose LPS failed to activate NF- $\kappa \mathrm{B}$. Instead, it selectively activated the transcription factor CCAAT/enhancer-binding protein $\delta$ and removed nuclear repressors on the promoter regions of proinflammatory mediators, leading to a mild and sustained inflammation (Maitra et al., 2011). In an attempt to reveal the dynamics of these cellular pathways, Sung and colleagues (2014) examined LPSinduced NF- $\kappa \mathrm{B}$ activity in single macrophages. They observed that subcritical doses of LPS induce predominantly negative feedback genes, preventing a sufficient response in the macrophage, whereas in response to high doses of LPS, amplification of NF- $\kappa \mathrm{B}$ becomes a dominant positive feedback loop, which overcomes the negative feedback signals and enables a robust immune response. This exciting work demonstrated that the switch from predominantly NF- $\kappa \mathrm{B}$ negative feedback to positive feedback enabled the cells to discriminate among various levels of LPS (Sung et al., 2014).

\section{THE COMPLEX BIOLOGY OF THE TRANSITION DAIRY COW}

A complete understanding of transition cow biology requires a truly integrative perspective. Compared with the late-gestation cow, the postpartum cow displays obvious changes in behavior, particularly in feeding behavior (Grant and Albright, 1995; Huzzey et al., 2005). Less visible but critically important shifts in physiology include altered blood flow patterns (Lomax and Baird, 
1983) and tissue growth (liver and mammary; Andrew et al., 1994) as well as tissue catabolism (adipose, muscle, and bone; McNamara, 2012; von Soosten et al., 2012). Focusing more tightly, alterations in circulating metabolites, hormones, and neuroendocrine factors reflect the homeorhetic changes that support and drive alterations in metabolic flux and tissue function (Bell, 1995; Ingvartsen, 2006; Kuhla et al., 2011). Major shifts in immune cell populations and function occur simultaneously (Mallard et al., 1998; Sordillo and Streicher, 2002). Finally, transcriptional (Loor, 2010) and perhaps even epigenetic (Singh et al., 2012) changes underlie these systemic responses at the cellular level. Readers new to this field are encouraged to refer to the excellent reviews cited above for a more comprehensive overview of the metabolic, immunological, and endocrine changes in the transition period. The remainder of this review will focus on the evidence regarding the role of inflammation in these adaptations.

\section{PREVALENCE AND CAUSES OF INFLAMMATION DURING THE TRANSITION TO LACTATION}

The presence of an inflammatory state in the postpartum period has been documented in several species, including cattle (Humblet et al., 2006), mice (Gregor et al., 2013), pigs (Rosenbaum et al., 2012a,b), and humans (DiSilvestro, 1986). An acute-phase response in postpartum dairy cows is particularly well established. Although early studies focused on associations between inflammatory markers and diseases such as mastitis and metritis, numerous studies in the past decade have demonstrated that inflammatory and positive acutephase mediators are elevated in the days after parturition, even in the absence of disease (Bionaz et al., 2007; Huzzey et al., 2009; Graugnard et al., 2012; Mullins et al., 2012; Akbar et al., 2015). One recent study (Qu et al., 2014), in which 161 transition cows were monitored, found that the acute-phase protein haptoglobin was elevated in serum around parturition, even in cows that were apparently healthy, but cows that experienced diseases or calving difficulties had significantly greater concentrations compared with healthy animals.

Damage to uterine tissue during parturition leads to inflammation that likely contributes to the systemic condition. To monitor inflammation in the reproductive tract, we used the cytobrush technique to collect cervical samples comprised of endometrial and inflammatory cells on d 7 and 42 postpartum in 40 multiparous cows (Yuan et al., 2015). As expected, uterine neutrophil populations and the transcript abundance of IL-6, IL-8, neutrophil myeloperoxidase, and neutrophil elastase genes were much greater in samples collected on $\mathrm{d} 7$ than in those from $\mathrm{d} 42$, reflecting neutrophil infiltration and increased production of proinflammatory mediators in the uterus immediately after calving.

In addition to the uterus, tissue transcript profiling has revealed inflammatory states in liver and adipose tissue in the first week of lactation (Loor et al., 2005; Sadri et al., 2010; Saremi et al., 2012; Gessner et al., 2013). Furthermore, a study of 240 multiparous cows demonstrated that elevated plasma haptoglobin concentrations from 2 to $8 \mathrm{~d}$ postpartum were associated with enhanced innate immune responses (Nightingale et al., 2015). These findings provide evidence that, at least in the most affected cows, high acute-phase protein concentrations are associated with a systemic inflammatory state and not simply liver inflammation.

Feeding high-grain diets to dairy cows alters the environment and microbiota in the gut, leading to the release of large amounts of LPS from bacteria, and subsequently induces inflammatory responses. Emmanuel et al. (2008) reported that feeding increasing proportions of barley grain decreased feed intake and rumen $\mathrm{pH}$ and increased ruminal LPS concentrations by more than 10-fold in lactating dairy cows. This response was associated with elevated plasma concentrations of acute-phase proteins, indicating that systemic inflammation occurred. Although this subacute ruminal acidosis induction model is more extreme than what most cows would experience on a dairy, the sudden shift from dry-cow diets to high-grain lactation diets could cause similar responses (Gott et al., 2015). Some recent evidence suggests that even relatively short-term feed withdrawal can induce an acute-phase response (Marques et al., 2012), possibly through disruption of gut barrier function (Pearce et al., 2013), which is particularly relevant given the erratic feeding behavior of periparturient cows. The combination of an altered rumen environment and a more "leaky" gut, particularly in heat stress conditions, may contribute to LPSinduced inflammation during this time.

Other potential contributors to periparturient inflammation are more speculative but nonetheless warrant consideration. Limited evidence from rodent studies suggests that psychosocial stress, often induced by isolation or immobilization, can promote liver inflammation, oxidative stress, and hepatocyte apoptosis (Depke et al., 2009). These links are thought to be mediated largely through glucocorticoid and catecholamine signaling originating in the central nervous system (Chida et al., 2006). This area of investigation is worth mentioning because of the many social stressors for cows during the transition to lactation, although there has been little concrete evidence that minimizing group disruptions can improve health or production outcomes when stocking rates are appropriate (Silva et al., 2013). Another potential contributor to systemic inflamma- 
tion is heat stress. Increases in inflammatory cytokines have been reported following heat stress in 2 studies with dairy cattle (Tao et al., 2013; Zhang et al., 2014). The biology of heat stress is complex enough that it is difficult to separate direct and indirect responses, but one possible link is the heat shock protein family. These proteins serve as molecular chaperones and are upregulated to promote normal protein folding during heat stress; when released extracellularly, though, they also serve as ligands for the PRR TLR2 and TLR4, which can drive inflammatory responses (Galloway et al., 2008). In fact, TLR4 plays a critical protective role in survival after heatstroke in mice (Dehbi et al., 2012), indicating that some aspect of the heat stress response does activate this receptor. Heat stress also may contribute to inflammation indirectly by promoting gut leakiness, as demonstrated in monogastric species (Pearce et al., 2013).

In addition to the triggers above, at least some earlylactation cows have an obvious cause of inflammation in the form of clinical or subclinical infections. Infectious diseases are more prevalent in early lactation than in other parts of the production cycle (Steeneveld et al., 2008; Dubuc et al., 2010), and both uterine (Huzzey et al., 2009; Akbar et al., 2014) and mammary (Hoeben et al., 2000) infections can result in systemic inflammation.

It is apparent that inflammatory signaling is elevated in several organs in the postpartum cow, with no obvious focal organ (Figure 2). This growing body of evidence suggests that either the processes of parturition and galactopoiesis induce inflammation directly or that infections (or LPS absorption) affect far more postpartum cows than is currently recognized. Unlike the inflammation associated with acute infection, the postpartum inflammatory state is often low grade without the classical signs of inflammation, which is consistent with the concept of metabolic inflammation (Hotamisligil, 2006); however, the signal(s) that are key to initiating this inflammatory state remain unclear and may vary by organ.

\section{Eicosanoids}

As a family of signaling molecules produced by oxidation of long-chain fatty acids, eicosanoids exert complex control over inflammation and can either enhance (as do certain types of prostaglandins, thromboxanes, and

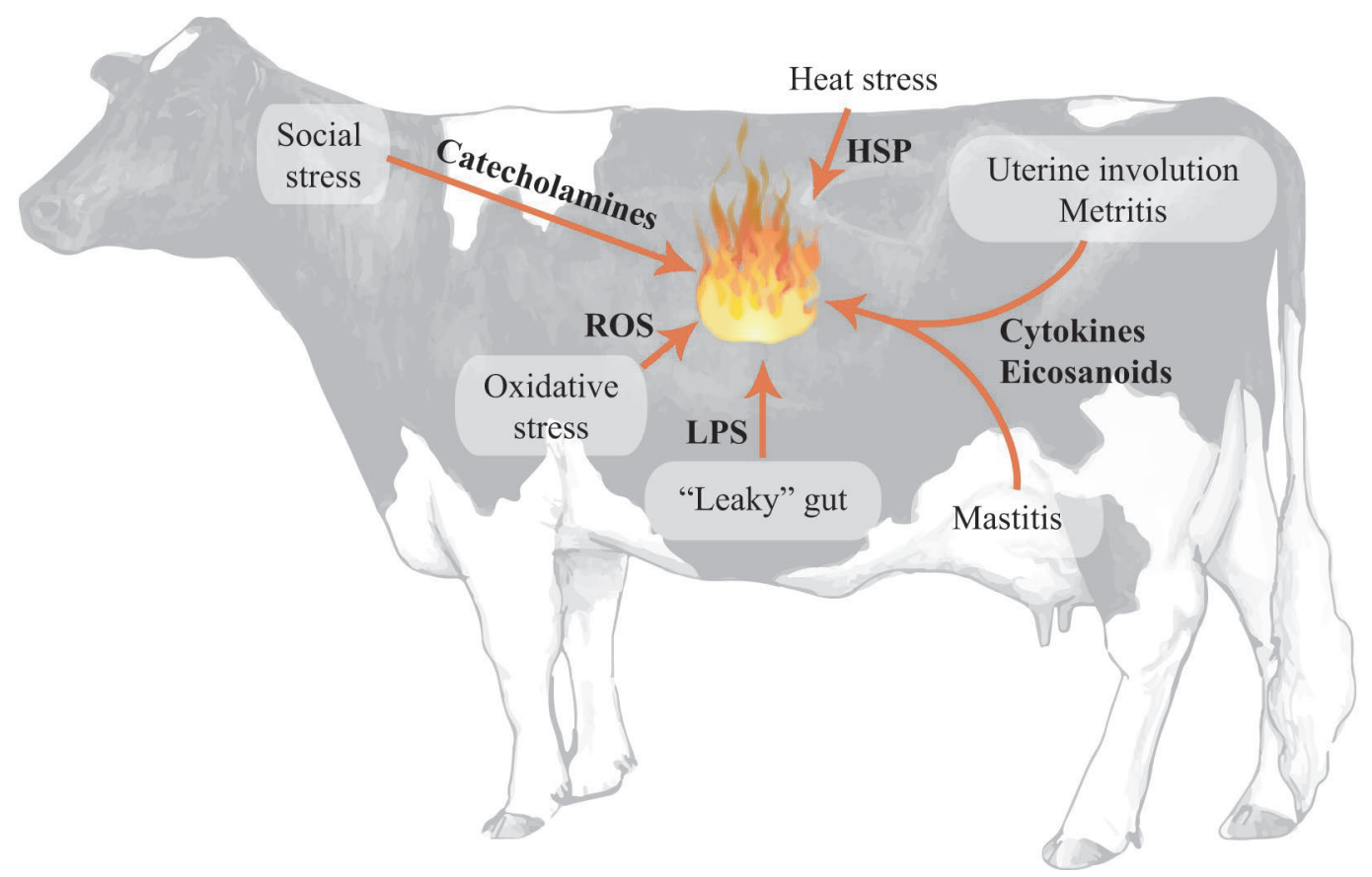

Figure 2. Diverse stressors may contribute to systemic inflammation. The wide variety of signals that converge to drive inflammatory processes (Figure 1) is derived from a broad list of systemic stressors. Social stress and heat stress can promote inflammatory transcription patterns via autonomic catecholamine release and bloodborne heat shock proteins (HSP), respectively. Tissue damage associated with parturition and subsequent uterine involution, as well as infections such as metritis and mastitis, result in leukocyte activation and release of inflammatory cytokines and eicosanoids. Various dietary and environmental conditions can decrease barrier function of the gut, allowing translocation of LPS into the bloodstream. Excess circulating lipids and low antioxidant status are associated with oxidative stress, which occurs when free radicals cause chain reactions, thus producing reactive oxygen species (ROS) that promote inflammation. Color version available online. 
leukotrienes) or resolve (as do resolvins, protectins, and maresins) inflammatory responses depending on their types and the timing of production (Sordillo et al., 2009). In a recent study (Yuan et al., 2013), we measured plasma concentrations of 16 different eicosanoids in the first week of lactation. We found that concentrations of pro-inflammatory eicosanoids, including certain types of prostaglandins and thromboxanes, were elevated around parturition and decreased during the first week of lactation, whereas pro-resolving metabolites, such as resolvin D2 and 7-maresin 1, increased after parturition. Therefore, in addition to supporting the previous findings that cows experience increased inflammation immediately postpartum, these data also demonstrated an increase in anti-inflammatory signals during the resolution of inflammation as lactation proceeds. We also found that low-dose administration of $\mathrm{TNF} \alpha$ did not significantly influence pro-inflammatory eicosanoid concentrations but did prevent the increase in anti-inflammatory species during the critical first week postpartum (Yuan et al., 2013).

\section{Lipids and Oxidative Metabolites}

Lipid peroxides are potential mediators that link elevated plasma lipids in early lactation to inflammation. Lipid peroxides are produced when intracellular lipids encounter ROS such as hydrogen peroxide. Some ROS are always produced in the liver; however, events occurring in early lactation likely contribute to enhanced ROS production. One adaptation to increasing delivery of NEFA to the liver in early lactation is an increase in the capacity of peroxisomal oxidation (Grum et al., 1996), an alternative pathway for FA oxidation. Enhanced peroxisomal oxidation increases the total oxidative capacity of the hepatocyte. The first step in this pathway, however, produces hydrogen peroxide rather than nicotinamide adenine dinucleotide (NADH), so it contributes to ROS production to a greater extent than mitochondrial oxidation. Increased ROS production in early lactation cows, coupled with increased NEFA concentration, increases lipid peroxide formation. Another key source of ROS in the transition period is phagocytic leukocytes, particularly in uterine tissue (Sordillo et al., 2009).

The proposed links between body fat mobilization and oxidative stress provide a possible means of connecting the well-established risks of excessive body condition at calving (Morrow, 1976; Ingvartsen, 2006) to inflammatory mechanisms, and several studies have begun to evaluate this link. Contreras et al. (2012) clearly showed that increasing concentrations of physiological NEFA mixtures increased ROS in bovine endothelial cells but had mixed effects on inflammatory mediators, including reductions in expression of some inflammatory cytokines. Likewise, in vivo observations of the role of oxidative stress in inflammatory conditions have been inconsistent. Both the transition to lactation and high body condition are associated with increased plasma markers of lipid peroxidation (Bernabucci et al., 2005), and dairy cows with fatty liver had lower antioxidant status and higher hepatic lipid peroxide concentrations than healthy cows (Mudron et al., 1999). Regarding the link to inflammation, however, studies have failed to consistently link excessive body condition (Akbar et al., 2015) or plasma NEFA concentration (Gessner et al., 2013; Nightingale et al., 2015) with elevated hepatic inflammation. Such studies are admittedly difficult to compare, because differences in antioxidant status of cows across studies likely contributes greatly to the degree of oxidative stress experienced (Sordillo et al., 2009). At this time, there is no convincing link between mobilized body lipids and systemic inflammation in the periparturient cow, the other problems associated with hyperlipidemia and oxidative stress notwithstanding. Oxidative stress is likely to interfere with resolution of inflammation, and links between excess lipids and the persistence of postpartum inflammation need to be evaluated.

\section{Pro-Inflammatory Cytokines}

Although a variety of circulating inflammatory markers are elevated in the immediate postpartum period, serum inflammatory cytokine concentrations are often suppressed in healthy cows during this time compared with prepartum time points (Ishikawa et al., 2004; Schoenberg et al., 2011). Still, a substantial proportion of transition cows are not healthy, and activation of the immune system by infections during this period is thought to lead to an exaggerated cytokine response (Sordillo et al., 1995), which can promote systemic inflammation and delay the resolving phase of the immune response.

\section{THE ROLE OF SUBACUTE INFLAMMATION IN TRANSITION DISORDERS}

\section{Inflammation Directly Affects Metabolic Function}

Immune activation involves large and rapid increases in leukocyte populations and activity and, as a result, numerous tissues must alter their metabolism to provide or spare fuels needed to support the increased immune activities (Wolowczuk et al., 2008). Many immune cells, such as neutrophils and macrophages, rely heavily on circulating glucose to meet their metabolic needs, which can divert large amounts of nutrients that 
could be used for production and normal physiological function. One mechanism driving this reallocation of resources is insulin resistance, which is directly induced by inflammatory signals (Odegaard and Chawla, 2012). Exaggerated insulin resistance in transition cows may exacerbate lipid mobilization and impair metabolic health (Ohtsuka et al., 2001; Zachut et al., 2013).

The association between inflammation and periparturient diseases is well established. Ametaj et al. (2005) reported that plasma concentrations of inflammatory markers, including the positive acute-phase proteins haptoglobin and serum amyloid A, were elevated in cows that developed fatty liver. Similarly, Ohtsuka et al. (2001) observed increased serum TNF $\alpha$ activity in cows with moderate to severe fatty liver. A larger retrospective study of cows on 3 commercial Italian dairies suggested that liver inflammation is associated with a problematic transition to lactation (Bertoni et al., 2008). Cows were classified in quartiles for degree of liver inflammation primarily based on plasma concentrations of acute-phase proteins. Those cows with the strongest inflammatory profiles were at 8-fold greater risk for experiencing one or more transition disorders, had lower plasma calcium concentrations, took longer to rebreed, and produced less milk in the first month of lactation (Bertoni et al., 2008). Similar links between acute-phase proteins and periparturient diseases have been reported in numerous studies, often before clinical signs are apparent (Huzzey et al., 2009; Dubuc et al., 2010; Qu et al., 2014).

Although strong links have been established between inflammatory markers and periparturient diseases, the interpretation of such associative data is difficult. It is possible that inflammation contributes to the etiology of some common early-lactation disorders, and the chronology of events in some studies does suggest this, but it is also possible that undiagnosed subclinical conditions cause an increase in inflammatory mediators before disease diagnosis; in this scenario, the inflammatory state is an effect of the disease rather than a cause. The impact of inflammation on metabolic function of transition dairy cows has been directly assessed following exogenous administration of inflammatory agents in several studies. Interpretation of these findings is complicated by various routes of administration, doses, and agents.

Transient Acute Inflammatory Challenges. Among the most careful assessments of the metabolic responses to an acute mammary inflammatory event was carried out by Waldron et al. (2006). The study was designed to evaluate whether mastitis induced by gram-negative bacteria could directly lead to common periparturient metabolic disorders. Cows in early lacta- tion were challenged with intramammary administration of $100 \mu \mathrm{g}$ of LPS and closely monitored for the subsequent $8 \mathrm{~h}$. This treatment induced acute systemic inflammation, resulting in a $3^{\circ} \mathrm{C}$ increase in rectal temperature, a $29 \%$ increase in heart rate, and a 15 -fold increase in plasma cortisol concentrations. Contrary to expectations, this inflammatory challenge increased the rate of glucose appearance (a proxy for hepatic glucose release) in the face of a 3 -fold increase in plasma insulin concentration, and metabolites associated with metabolic disease were largely unaffected (Waldron et al., 2006). Not surprisingly, the authors concluded that this model of inflammation does not directly impair metabolic function but, as they pointed out, this approach was intended to model only the very early stages of mastitis. The increase in plasma glucose rate of appearance in this early stage likely reflects acute glycogenolysis (Virkamäki and Yki-Järvinen, 1995), which would not be sustained chronically. Nevertheless, the findings of Waldron and colleagues (2006) suggest that periparturient cows could recover metabolic homeostasis following an acute but transient inflammatory event.

Sustained Subacute Inflammatory Challenges. One key hypothesis drawn from the obesity research community has been that the metabolic risks associated with excessive body condition at calving may be caused by immune cell infiltration of adipose tissue (Ji et al., 2014). To evaluate whether stable but low-level secretion of inflammatory cytokines disrupts metabolic function, we used osmotic minipumps to deliver bovine TNFa continuously into a subcutaneous adipose depot of late-lactation cows for $7 \mathrm{~d}$ (Martel et al., 2014). The dose and duration of treatment in this experiment matched that of a previous study that had been shown to disrupt metabolism (Bradford et al., 2009); treatments differed only in method and site of administration. Contrary to our hypothesis, consistent delivery of TNFa into the adipose depot site did not alter metabolic function in any quantifiable manner, as feed intake, glucose production, and plasma metabolite concentrations were all similar across treatments. Part of the reason for this lack of response may have been the slow rate of delivery by minipump infusion, which may not have been sufficient to trigger the cytokine storm necessary to drive systemic effects. However, we also observed a dramatic increase in protein abundance of the anti-inflammatory cytokine IL-10 in the contralateral adipose depot. This surprising finding demonstrated that the lack of response to this infusion protocol was not simply a passive process but rather (at least in part) the result of mechanisms that counteract the inflammatory signal (Martel et al., 2014). It is not clear whether the periparturient cow has a similar 
ability to counteract subacute inflammatory stressors. Combined with recent reports documenting the very limited quantity of immune cells found in the adipose tissue of lactating dairy cows (Akter et al., 2012), however, these findings have decreased our enthusiasm for an adipose-centric model of inflammation in transition cows. Perhaps it is not surprising that dairy cows, with a typical body fat content of $\sim 20 \%$ at parturition (von Soosten et al., 2012), may not show the degree of adipose tissue inflammation observed in human obesity, where body fat can often exceed $40 \%$ (Kern et al., 2001; Cinti et al., 2005) for years.

Repeated Transient Inflammatory Challenges. In the first evaluation of the effects of systemic delivery of a recombinant cytokine to lactating cows, Kushibiki et al. (2003) injected subacute doses of TNFa once daily by subcutaneous injection during mid-lactation. This treatment decreased feed intake by $34 \%$, elevated plasma NEFA concentrations, and increased markers of oxidative stress. Using a similar approach with a slightly lower dose, we reported that daily subcutaneous injection of recombinant bovine TNFo for $7 \mathrm{~d}$ doubled liver triglyceride content in late-lactation dairy cows, and we detected evidence of transcriptional alterations in the liver promoting fatty acid uptake and storage and decreased fatty acid oxidation (Bradford et al., 2009). In a third study with a similar design, Yuan et al. (2013) reported that TNFo treatment in early-lactation cows decreased feed intake by $18 \%$ and increased the incidence of ketosis by 3 -fold, although liver TG concentrations and other lipid metabolism markers were unaffected. Using a different approach, Trevisi and colleagues (2009) orally administered interferon- $\alpha$ daily during the final 2 wk of gestation, which elevated acute-phase proteins after parturition. Compared with controls, treated cows had significantly increased plasma BHBA concentrations and decreased serum retinol during the transition to lactation. These studies all supported the hypothesis that repeated subacute inflammatory challenges can disrupt homeostasis and promote metabolic disorders in lactating cows.

Summary of Inflammatory Effects on Metabolic Function. Current evidence of the direct effects of inflammation on metabolic function in lactating dairy cattle is summarized in Figure 3. Although neither transient acute inflammation nor continuous administration of inflammatory mediators has disrupted metabolic homeostasis, 4 separate studies have now demonstrated that repeated boluses of inflammatory agents, even at very low doses, can promote metabolic dysfunction through suppression of DMI, alteration of postabsorptive metabolism, or both. This model aligns with the "multiple hit" hypothesis that has been pro- posed for the etiology of human fatty liver disease (Tilg and Moschen, 2010).

\section{Inflammation Can Impair Milk Production}

Immune system activation is an energy-demanding process that necessitates a reallocation of nutrients and energy from dispensable functions such as growth and production. Using the fruit fly Drosophila as a model, DiAngelo et al. (2009) demonstrated that activation of the toll inflammatory pathway in the fat body, the major immune and lipid storage organ of the fruit fly, suppressed insulin signaling throughout the organism and subsequently decreased nutrient stores and growth. Similarly, overexpression of NF- $\kappa \mathrm{B}$ increased energy expenditure and prevented BW gain in mice (Tang et al., 2010). These and other studies (Mireles et al., 2005) suggest that inflammation repartitions nutrient utilization and decreases energy available for productive uses.

In dairy cows, both observational and controlled studies have supported the hypothesis that inflammation decreases milk production. One metric that has been used in associative studies is paraoxonase, a liver-derived bloodborne antioxidant that is potently suppressed by a variety of inflammatory stimuli (a negative acute-phase protein). Transition cows with high paraoxonase concentrations, in addition to having lesser concentrations of positive acute-phase proteins and reactive oxygen metabolites, produced $1,971 \mathrm{~kg}$ more milk $(24 \%)$ over $305 \mathrm{~d}$ than those in the lowest quartile for paraoxonase (Bionaz et al., 2007). Bertoni et al. (2008) reported that cows in the highest quartile for a composite index of inflammatory markers produced $20 \%$ less milk during the first month of lactation than those in the lowest quartile. Similarly, postpartum plasma concentrations of haptoglobin greater than 1.1 $\mathrm{g} / \mathrm{L}$ were associated with a $947-\mathrm{kg}$ decrease in $305-\mathrm{d}$ mature-equivalent milk yield (Huzzey et al., 2012).

We recently reported that $\mathrm{TNF} \alpha$ injection during the first $7 \mathrm{~d}$ of lactation at 1.5 or $3.0 \mu \mathrm{g} / \mathrm{kg}$ of $\mathrm{BW}$ decreased the yield of milk and milk components by 15 to $18 \%$ (Yuan et al., 2013). In mid-lactation cows, a similar TNF $\alpha$ administration protocol caused a $15 \%$ reduction in milk yield (Kushibiki et al., 2003). A large number of studies have demonstrated the negative effect of intramammary LPS, often at doses sufficient to cause acute inflammation, on milk production (Ballou, 2012). Because the immune system of the cow responds to these challenges as if they signaled infection, decreased milk production in response to inflammatory mediators reflects a resource allocation tradeoff. In these scenarios, the dam sacrifices some milk yield (and, evolutionarily, offspring fitness) in exchange for 
A

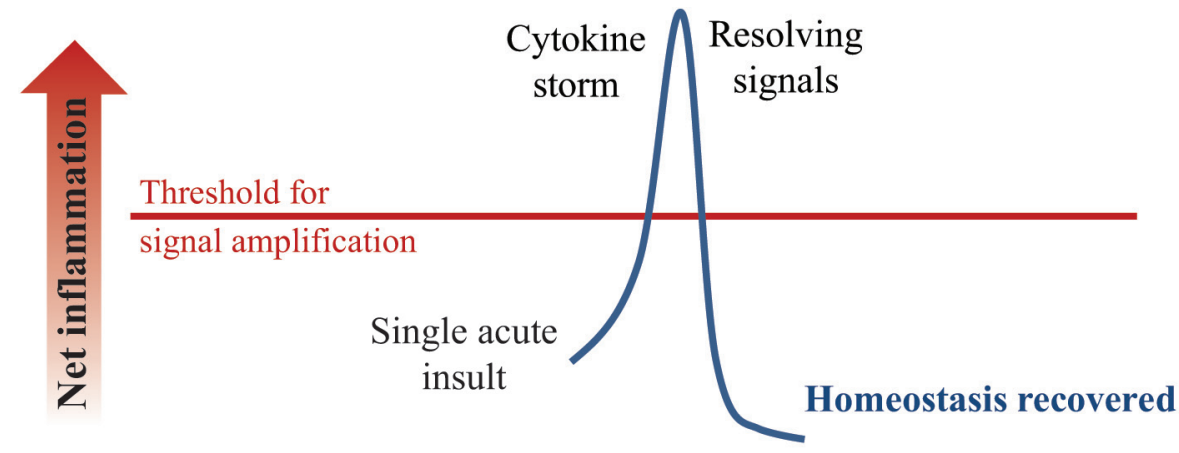

B

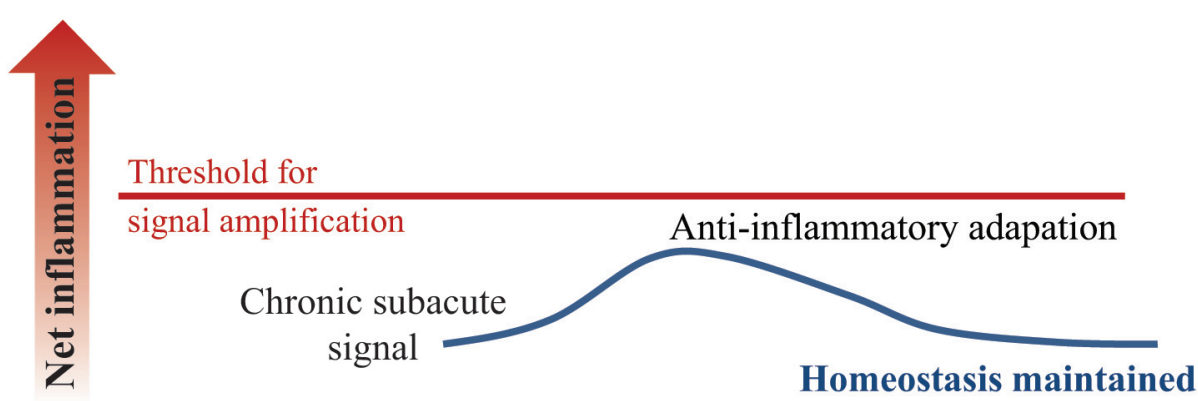

C

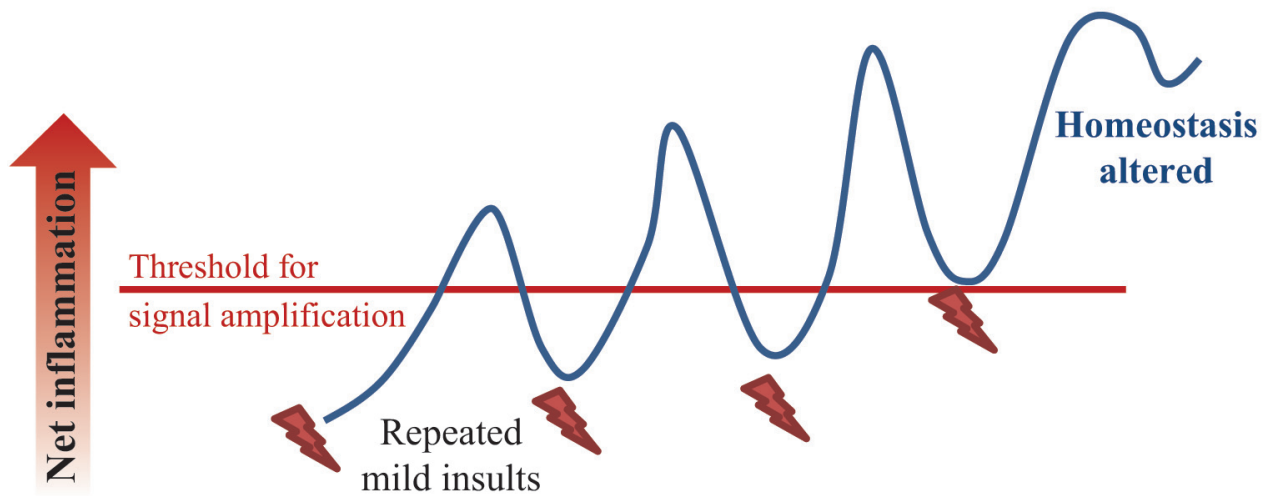

Figure 3. Summary of metabolic responses to exogenous inflammatory agents in lactating dairy cows. (A) Single acute inflammatory events are often resolved quickly, and there is little evidence that systemic metabolism is disrupted in these scenarios. (B) Chronic administration of very low doses of inflammatory agents can result in an anti-inflammatory response to prevent a cytokine storm and maintain homeostasis. (C) Repeated inflammatory insults, even at low doses, can alter metabolic homeostasis. Color version available online.

survival and the potential to have future offspring (Ballou, 2012). Whether or not this conserved response confers fitness in the controlled setting of a dairy farm with a readily available nutrient supply, however, is unclear. Furthermore, because few studies have assessed mammary tissue-level responses to inflammatory stimuli, the exact mechanisms underlying decreased milk yield in response to inflammation remain poorly documented in the cow.

\section{REQUIREMENTS AND ADAPTIVE ROLES FOR INFLAMMATORY PATHWAYS IN THE TRANSITION COW}

Despite the deleterious effects of excessive inflammation, a certain degree of inflammation is likely necessary to support physiological adaptations in the transition period. One key role of inflammation in the transition cow is to facilitate parturition. Parturition is character- 
ized by a massive influx of macrophages and neutrophils into the myometrium; this proinflammatory environment promotes dilation of the cervix, contraction of the uterus, rupture of the fetal membranes, and expulsion of the placenta (Challis et al., 2009; van Engelen et al., 2009). Cyclo-oxygenase-mediated production of prostaglandin $\mathrm{F}_{2 \alpha}$ is required to trigger oxytocin receptor expression in the uterus, which is in turn required for oxytocin-induced parturient uterine contractions (Sugimoto et al., 1997). Indeed, the nonsteroidal anti-inflammatory drug (NSAID) aspirin can disrupt parturition (Lewis and Schulman, 1973; Williams and Vane, 1975). Flunixin meglumine, another NSAID, was shown to increase the risk of retained placenta following Caesarean section (Waelchli et al., 1999) and normal parturition (Duffield et al., 2009). Additional evidence for the role of inflammation in placental detachment comes from a recent publication documenting decreased expression of a variety of inflammatory mediators in retained uteroplacental tissues compared with placental tissue that was expelled normally (Boro et al., 2014).

Perhaps the most recognized benefit of inflammation is its role in clearance of pathogens and resolution of infections. Given that the incidence of infections increases dramatically in early lactation, activation of inflammatory pathways may help cows fight off diseases. Inflammation is a key tool used by the innate immune system as well as an activating factor for the adaptive immune system (Newton and Dixit, 2012). Genetically altered mouse models provide the clearest demonstration of the essentiality of inflammatory signaling for immune defense; for example, influenza is more lethal in mice deficient in IL-1 $\beta$ than in wild types (Kozak et al., 1995), TNFo receptor deficiency dramatically increases mortality following listeria infection (Pfeffer et al., 1993), and TLR4 deletion increases susceptibility to pneumococcal infection (Malley et al., 2003). Even transgenic introduction of $\mathrm{n}-3$ desaturase activity in mice, providing the capacity for endogenous n-3 fatty acid synthesis, is sufficient to increase susceptibility to tuberculosis infection (Bonilla et al., 2010). In addition to being a key stimulus driving pathogen clearance mechanisms, inflammation was recently shown to contribute to wound healing (Liu et al., 2014). The inflammatory eicosanoid 12-HHT promotes keratinocyte migration to close the wound, a process that is inhibited by aspirin.

One key mechanism that supports copious milk synthesis and secretion in dairy cows is insulin resistance, which diverts the nutrients away from peripheral adipose tissue and muscle to the mammary gland (Bell, 1995). The mechanisms initiating this adaptive insulin resistance in early lactation are not clear. Because inflammation of muscle and adipose tissue is tightly linked to insulin resistance in many metabolic scenarios (Odegaard and Chawla, 2013), it is possible that endogenous inflammation in early lactation is needed to promote insulin resistance and protect metabolic homeostasis as nutrient demands for the mammary gland increase.

To investigate the role of inflammatory pathways in promoting homeorhetic adaptations, we treated cows with the NSAID sodium salicylate (SS) for the first $7 \mathrm{~d}$ of lactation (Farney et al., 2013a). Although SS only mildly suppressed the inflammatory mediators measured in liver and plasma during treatment, proinflammatory eicosanoids in plasma dramatically increased after cessation of SS treatment, suggesting that our treatment regimen did alter inflammatory signaling. Furthermore, we observed clear effects on nutrient metabolism. Among the most interesting findings was that SS decreased plasma glucose concentration. Given the negligible net uptake of glucose from the ruminant gut (Allen et al., 2005), SS-induced hypoglycemia must have been caused by some combination of decreased gluconeogenesis and increased clearance of circulating glucose. The decrease in plasma glucose was not explained by altered milk lactose secretion (1.25 vs. 1.26 $\pm 0.06 \mathrm{~kg} / \mathrm{d} ; P=0.90$ ), suggesting that the mammary gland was not likely the cause of this change. Insulin concentrations were decreased in SS-treated cows on d 7 compared with controls, which is consistent with the decline in plasma glucose concentration. Because insulin concentration did not point to an increase in insulin-dependent glucose uptake, we next used the revised quantitative insulin sensitivity check index (RQUICKI; Holtenius and Holtenius, 2007) to assess whether altered insulin sensitivity may have influenced glucose utilization rate with SS. The RQUICKI estimate of insulin sensitivity was significantly elevated by SS on d 7, coincident with the decline in plasma glucose concentration. The findings suggest that SS may have increased insulin sensitivity, promoting excessive glucose utilization in peripheral tissues and (or) suppressing gluconeogenesis, leading to hypoglycemia. We therefore proposed that inflammation-induced insulin resistance may be adaptive during early lactation and may help clarify why the links between inflammation and metabolism are evolutionarily conserved (Farney et al., 2013a).

Other evidence suggests that inflammation is a mechanism for regulating nutrient partitioning and energy balance. In obesity, for example, increased inflammation may act as a feedback response to promote energy expenditure and limit further energy accumulation (Tang et al., 2010). Conversely, a decrease in inflammation under caloric restriction contributes to energy savings (Ye and Keller, 2010). Given the dramatic al- 
terations in nutrient demand during the transition to lactation, inflammation likely plays an unappreciated role in the homeorhetic shifts in metabolism required for a successful transition period.

Finally, numerous studies have now identified critical roles that inflammatory signals play in normal tissue development and remodeling. Prenatal liver development and tissue regeneration following partial hepatectomy are clearly driven in part by inflammatory transcriptional programs (Seki et al., 2012), although it is unclear whether liver hyperplasia in early lactation is likewise inflammation-dependent. A large body of work details the central role of inflammatory signals in mammary gland development, lactogenesis, galactopoiesis, and involution (Vorbach et al., 2006; Nørgaard et al., 2008; Watson, 2009). In fact, a transgenic mouse model with decreased mammary NF- $\kappa \mathrm{B}$ signaling had impaired prepartum proliferation of mammary epithelial cells, ultimately resulting in the starvation of pups from lack of milk (Cao et al., 2001). Perhaps most surprisingly, despite the large amount of research on pathological forms of adipose tissue inflammation, 3 genetically altered mouse models with disrupted adipose tissue inflammatory signaling all suffered from forms of lipodystrophy, including massive ectopic lipid storage and leaky gut, because of impaired adipogenesis (Wernstedt Asterholm et al., 2014). These many effects of inflammatory signals place these pathways in a central role in developmental physiology, not simply during disease challenges.

\section{Is Rapid Resolution of Postpartum Inflammation a Critical Factor?}

Although several relatively large-scale studies have investigated associations between early-lactation markers of inflammation and outcomes such as subsequent disease, fertility, and productivity, these studies generally have relied on a single blood sample collected during a 1- to 2 -wk period at the beginning of lactation. The balance between necessary and maladaptive aspects of inflammation during this time, however, suggests that a simple demarcation between normal and inflamed cows is likely too simplistic. Rather, we propose that the intensity and timing of inflammation in combination with the timing of its resolution may be more critical than whether or not an inflammatory state occurs at all.

The concept that failure of resolution is a large contributor to the pathology of inflammatory disorders has been well accepted in the biomedical literature. To name a few examples, delayed resolution has been implicated in the etiology of obesity, metabolic syndrome (Monteiro and Azevedo, 2010), and cancer (Coussens and Werb, 2002), and numerous reviews have been written on the problem of nonresolution and its corresponding mechanisms (Nathan and Ding, 2010; Serhan, 2011). Some results that support this premise in dairy cattle have been presented in our preceding discussion of inflammation; repeated low-dose administration of $\mathrm{TNF} \alpha$ in early lactation delayed the increase of antiinflammatory eicosanoids responsible for resolution of inflammation (Yuan et al., 2013). Conversely, maintenance of metabolic homeostasis was associated with rapid resolution of inflammation in early-lactation cows challenged with intramammary LPS (Waldron et al., 2006). Some observational studies that have associated the postpartum acute-phase response with negative lactation outcomes have also documented a delayed resolution of inflammation in cows with greater peak concentrations of inflammatory markers, most notably Bionaz et al. (2007).

We hypothesize that rapid resolution of postpartum inflammation, rather than its complete avoidance, may allow for optimal adaptation to lactation (Figure 4). More large-scale observational studies with repeated samples collected over time will be required to assess whether this model accurately predicts health and production outcomes in dairy cattle.

\section{CONTROLLING THE FIRE: APPROACHES TO MODULATE INFLAMMATION}

\section{Nonsteroidal Anti-Inflammatory Drugs}

One approach to understanding the effects of transition cow inflammation has been to block these signals using NSAID. This class of drugs has been heavily studied across species, providing the advantage of having relatively well-established modes of action. Therefore, although off-target effects cannot be ruled out,

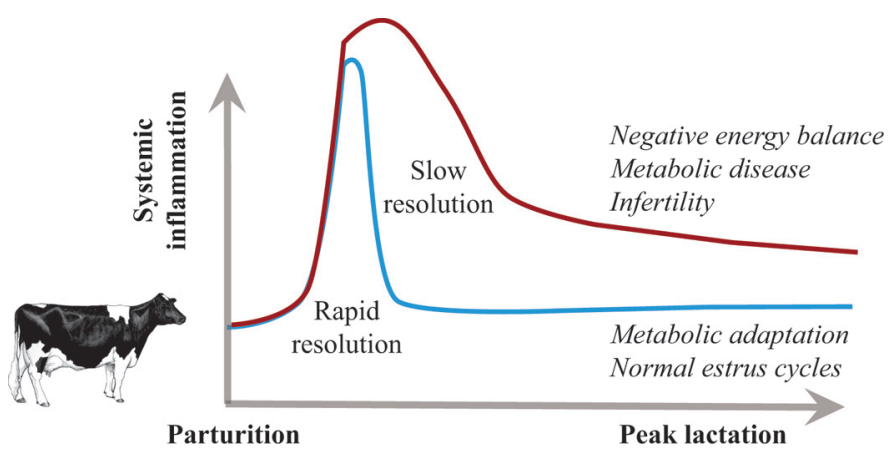

Figure 4. Hypothesized responses to resolved and unresolved inflammation in early-lactation dairy cows. Visualization of typical time courses of slowly resolved or quickly resolved inflammation, along with proposed production outcomes resulting from these different profiles. Color version available online. 
NSAID provide an opportunity to directly investigate the effects of suppressing endogenous inflammation in the transition cow.

Flunixin Meglumine. One of the most common NSAID tested on the transition dairy cow is flunixin meglumine, which has had varying effects. One study indicated that uterine involution was accelerated by flunixin meglumine treatment during metritis (Amiridis et al., 2001), but another showed no beneficial effects, either systemically or in the reproductive tract (Drillich et al., 2007). Most relevant to this review, Shwartz et al. (2009) showed no benefit from administration of flunixin meglumine for the first $3 \mathrm{~d}$ of lactation.

Salicylates. Salicylic acids (extracts of willow bark) have been utilized for therapeutic purposes for almost 2,000 yr, but the mechanisms underlying their anti-inflammatory effects continue to be revealed. Salicylate, at concentrations below $1 \mathrm{~m} M$ (Hawley et al., 2012), works primarily by inhibiting IKK- $\beta$ activity, preventing phosphorylation and cleavage of $\mathrm{I} \kappa \mathrm{B}$, thereby allowing this protein to keep NF- $\kappa \mathrm{B}$ sequestered in the cytosol to prevent inflammatory transcriptional activity (Kopp and Ghosh, 1994; Pierce et al., 1996). Most other NSAID, in contrast, directly inhibit cyclooxygenase activity (Tegeder et al., 2001) and do not necessarily induce the same metabolic effects as salicylate (Yuan et al., 2001).

The pharmacology of SS and acetylsalicylic acid (aspirin) are relatively well described in cattle and these NSAID have a serum half-life of approximately $30 \mathrm{~min}$ (Gingerich et al., 1975; Coetzee et al., 2007). Despite rapid clearance, multiple studies have demonstrated that early-lactation administration of salicylates can improve long-term milk yield responses. In an initial study, Bertoni et al. (2004) administered aspirin or a placebo to 11 cows/treatment for the first $5 \mathrm{~d}$ postpartum and monitored milk production through d 126 of lactation. Peak milk yield tended to increase with aspirin treatment. The same group subsequently conducted a similar study with 23 cows/treatment and found that aspirin treatment during the first $5 \mathrm{~d}$ of lactation increased milk yield through d 60 of lactation, with a $13 \%$ increase in peak milk yield (Trevisi and Bertoni, 2008). These studies were the first to demonstrate the potential for anti-inflammatory treatments to increase milk yield for a sustained period.

We recently reported results from a study with 78 Holstein cows assigned to control or SS treatment 12 to $36 \mathrm{~h}$ after calving continuing through d 7 of lactation (Farney et al., 2013a). Salicylate was delivered in drinking water, providing $123 \pm 6 \mathrm{~g} /$ cow daily. Milk production was unaffected during the week of SS treatment, but by wk 3 of lactation, SS-treated cows produced significantly more milk fat than controls. To gain insight into sustained responses to treatment, we used DHIA records to quantify 305-d yields of milk and milk components. Milk yield was 2,470 kg greater over the lactation in parity $3+\mathrm{SS}$ cows compared with controls (21\% increase), although milk yield tended to decrease by $8 \%$ in primiparous cows treated with SS. Furthermore, parity 3+ SS cows produced 30\% more milk fat over the lactation and tended to produce $14 \%$ more protein than controls in this parity group.

Surprisingly, the production responses to SS apparently were not a result of improved metabolic function. Our hypothesis was that SS would improve liver function and decrease fat mobilization, but SS-treated cows displayed decreased plasma glucose and increased plasma NEFA and BHBA concentrations in early lactation (Farney et al., 2013b).

Other NSAID. Numerous NSAID have been evaluated for the treatment of mastitis, and in general they are effective at reducing body temperatures but do not appear to decrease the severity of the infection (Morkoc et al., 1993). One intriguing finding was that meloxicam treatment during mastitis decreased the risk of removal from the herd by $58 \%$ in the 45 wk following treatment (McDougall et al., 2009). Carprofen was shown to partially alleviate the decrease in ruminal contractions during mastitis (Vangroenweghe et al., 2005), which could help prevent a subsequent displaced abomasum. Similarly, meloxicam administration $1 \mathrm{~d}$ after assisted calving increased time spent eating in the subsequent 24 h (Newby et al., 2013). In general, though, shortterm responses to NSAID treatment during inflammation have been unimpressive (Priest et al., 2013; Meier et al., 2014).

Potential Risks of NSAID Use. The potential utility of NSAID treatments in early lactation must be weighed against possible risks to animal health and the food supply. As discussed in the section above about requirements for inflammatory pathways, suppressing inflammation runs the risk of disrupting parturition and placental expulsion as well as slowing immune responses to infection. With appropriate timing, dosing, and drug selection, problems with retained placenta can be avoided (Farney et al., 2013b; Newby et al., 2014). Likewise, co-administration of NSAID with antibiotic treatment for mastitis does not necessarily appear to disrupt immune activation (Vangroenweghe et al., 2005) or increase disease recurrence (McDougall et al., 2009).

Beyond the potential adverse effects of disrupting normal inflammation, drug residues in milk and meat are a concern. Salicylates, although short-lived, have come under some scrutiny because of purported links 
with Reye's syndrome, and a 24 -h withdrawal period has been recommended for both milk and meat (Damian et al., 1997). Many other NSAID have established milk withdrawal times that often extend 3 to $5 \mathrm{~d}$ after treatment ends, creating logistic and financial barriers to broader use of NSAID for postpartum inflammation.

\section{LPS Vaccination}

A recent study (Zebeli et al., 2013) reported that repeated oral administration of LPS around calving improved the profile of plasma metabolites. The authors administered LPS at increasing doses and showed that treated cows had greater plasma concentrations of glucose and insulin and decreased NEFA and BHBA concentrations, findings consistent with reduced body fat mobilization. Lipopolysaccharide administration did not affect DMI, plasma cortisol, serum amyloid A, or haptoglobin (Ametaj et al., 2012). It is possible that oral LPS treatment induced an immune refractory state, known as LPS tolerance, resulting in a reduced inflammatory response to subsequent LPS exposure. Indeed, pretreatment of the udder with a low dose of LPS protected against experimental Escherichia coli mastitis (Petzl et al., 2012). Molecular mechanisms of LPS tolerance have been detailed, and this response serves to prevent excessive inflammation (Ziegler-Heitbrock, 1995). The efficacy of the oral LPS tolerance protocol suggests that LPS (or co-agonists for TLR4) may be a key contributor to the periparturient inflammation.

\section{Bioactive Fatty Acids}

Bioactive FA are important for the normal physiological function of animals. The n-3 class of FA includes $\alpha$-linolenic acid, eicosapentaenoic acid (EPA), and docosahexaenoic acid (DHA), and the latter 2 are known to suppress inflammatory pathways. Several recent studies have evaluated the use of flaxseed or fish oil-derived products to increase dietary supply of n-3 FA, and anti-inflammatory effects have been clearly demonstrated in cows (Greco et al., 2015). Lessard et al. (2003) reported that feeding transition cows with flaxseed (a source of $\alpha$-linolenic acid) increased serum n-3 FA concentrations; on d 5 postpartum, the lymphocyte proliferative response of cows fed flaxseed was reduced compared with cows that received n-6 FA supplements, suggesting that an anti-inflammatory effect was achieved. On the other hand, Silvestre and colleagues (2011) attempted to promote immune function in the transition period by supplementing calcium salts of n- 6 FA instead of n-3 FA. Increasing the ratio of n- 6 to n-3 FA increased the production of hydrogen peroxide and phagocytosis of bacteria by neutrophils and increased plasma concentrations of acute-phase proteins. Although increased neutrophil function may improve the ability of immune system to fight off infection, elevated acute-phase protein markers are a sign of subacute inflammation, which could impair metabolic function (Bertoni et al., 2008; Bradford et al., 2009). Therefore, further studies are needed to investigate if such an approach benefits clinical outcomes of transition cows.

\section{Antioxidants}

Dietary antioxidants, notably vitamin $\mathrm{E}$ and selenium, are important for their ability to neutralize ROS, thereby impeding the progression toward inflammation. This is particularly important in cows with high BCS at parturition because of their increased risk of oxidative stress (Bernabucci et al., 2005). Plasma concentrations of vitamin $\mathrm{E}$ decrease through the transition period (Weiss et al., 1990a), and low antioxidant status is associated with transition cow disorders (Mudron et al., 1997; LeBlanc et al., 2004). Supplementing vitamin E prepartum improves antioxidant status (Weiss et al., 1990b). Multiple studies have shown that supplementing vitamin $\mathrm{E}$ in excess of traditional recommendations decreases the incidence and severity of clinical mastitis (Smith et al., 1984; Weiss et al., 1990b; Politis, 2012). A meta-analysis also showed that supplemental vitamin $\mathrm{E}$ is effective at preventing retained placenta (Bourne et al., 2007).

Transition cow studies using antioxidants as treatments have looked almost exclusively at effects on infectious disorders such as mastitis and metritis. In rodent models, however, studies have demonstrated that antioxidants improve metabolic function in animals challenged with high-fat diets (Mao et al., 2010) and endotoxin (Sakaguchi and Furusawa, 2006). In a phase 3 clinical trial, vitamin E supplementation significantly improved liver health in steatohepatitis patients compared with a placebo (Sanyal et al., 2010). Therefore, antioxidants may have the potential to improve not only immunity but also metabolic health of transition cows (Bertoni et al., 2015).

\section{SMOLDERING QUESTIONS}

Our goal in this review has been to provide a roadmap to an intriguing portion of the "final frontier" of dairy cow biology, but much work remains to be done. Key remaining questions surrounding inflammation in early lactation include the following: 
- Does immunosuppression in the transition period contribute to elevated inflammation, or vice versa? Or are apparent relationships coincidental?

- What is the prevalence and duration of subacute inflammation in transition cows? What are the most important tissue sources of inflammatory molecules during the transition period?

- Mechanistically, how does subacute inflammation increase the risk of transition cow disorders?

- Does subacute inflammation directly affect mammary gland function and, subsequently, milk synthesis?

- Given the necessary role of inflammation in normal physiological function, should we inhibit inflammation in early lactation? How can we promote a healthy degree of inflammation while minimizing the pathological aspects?

- To what extent does the timing and duration of the resolving phase of inflammation contribute to pathology in transition cows?

- Can we develop nutritional strategies that selectively inhibit excessive inflammation while enhancing immune function?

\section{CONCLUSIONS}

It is now apparent that most dairy cattle, and perhaps most mammals, experience subacute inflammation for at least the first several days postpartum. Although more research is needed to evaluate the most common initiators of this inflammatory state, different lines of evidence suggest that signals derived from the uterus, mammary gland, gut, and nervous system may all contribute. Some degree of inflammation during this period is clearly important for normal function of the reproductive system, for immunity, and possibly for homeorhetic shifts in metabolism, but both prospective and controlled studies (using both pro- and antiinflammatory agents) suggest that a slightly elevated degree of inflammation can impair whole-lactation productivity of cows. These findings lead us to propose that treatment of postpartum inflammation with nutrients or pharmaceutical agents is worth exploring further, even though such approaches must be designed carefully to avoid disrupting the necessary roles of inflammatory signals. Improved tools for early diagnosis of cows with above-average inflammatory status, particularly cowside diagnostic assays, would improve our ability to evaluate whether targeted treatment of elevated systemic inflammation leads to better outcomes than blanket treatments. Defining and promoting a healthy degree of inflammation in transition cows may allow the dairy industry to limit transition disorders while improving productivity.

\section{ACKNOWLEDGMENTS}

This paper is contribution no. 15-359-J from the Kansas Agricultural Experiment Station. Work on this topic in our laboratory has been supported by Agriculture and Food Research Initiative Competitive Grants 2009-35206-05271 and 2014-67015-21621 from the US Department of Agriculture National Institute of Food and Agriculture (Washington, DC) and by a grant from Elanco Animal Health (Greenfield, IN).

\section{REFERENCES}

Akbar, H., F. C. Cardoso, S. Meier, C. Burke, S. McDougall, M. Mitchell, C. Walker, S. L. Rodriguez-Zas, R. E. Everts, H. A. Lewin, J. R. Roche, and J. J. Loor. 2014. Postpartal subclinical endometritis alters transcriptome profiles in liver and adipose tissue of dairy cows. Bioinform. Biol. Insights 8:45-63.

Akbar, H., T. M. Grala, M. Vailati Riboni, F. C. Cardoso, G. Verkerk, J. McGowan, K. Macdonald, J. Webster, K. Schutz, S. Meier, L. Matthews, J. R. Roche, and J. J. Loor. 2015. Body condition score at calving affects systemic and hepatic transcriptome indicators of inflammation and nutrient metabolism in grazing dairy cows. J. Dairy Sci. 98:1019-1032.

Akter, S. H., S. Haussler, D. Germeroth, D. von Soosten, S. Dänicke, K. H. Südekum, and H. Sauerwein. 2012. Immunohistochemical characterization of phagocytic immune cell infiltration into different adipose tissue depots of dairy cows during early lactation. J. Dairy Sci. 95:3032-3044.

Allen, M. S., B. J. Bradford, and K. J. Harvatine. 2005. The cow as a model to study food intake regulation. Annu. Rev. Nutr. $25: 523-547$.

Ametaj, B. N., B. J. Bradford, G. Bobe, R. A. Nafikov, Y. Lu, J. W. Young, and D. C. Beitz. 2005. Strong relationships between mediators of the acute phase response and fatty liver in dairy cows. Can. J. Anim. Sci. 85:165-175.

Ametaj, B. N., S. Sivaraman, S. M. Dunn, and Q. Zebeli. 2012. Repeated oral administration of lipopolysaccharide from Escherichia coli 0111:B4 modulated humoral immune responses in periparturient dairy cows. Innate Immun. 18:638-647.

Amiridis, G. S., L. Leontides, E. Tassos, P. Kostoulas, and G. C. Fthenakis. 2001. Flunixin meglumine accelerates uterine involution and shortens the calving-to-first-oestrus interval in cows with puerperal metritis. J. Vet. Pharmacol. Ther. 24:365-367.

Andrew, S. M., D. R. Waldo, and R. A. Erdman. 1994. Direct analysis of body composition of dairy cows at three physiological stages. J. Dairy Sci. 77:3022-3033.

Baker, R. G., M. S. Hayden, and S. Ghosh. 2011. NF-kB, inflammation, and metabolic disease. Cell Metab. 13:11-22.

Ballou, M. A. 2012. Growth and Development Symposium: Inflammation: Role in the etiology and pathophysiology of clinical mastitis in dairy cows. J. Anim. Sci. 90:1466-1478.

Banchereau, J., V. Pascual, and A. O'Garra. 2012. From IL-2 to IL37: The expanding spectrum of anti-inflammatory cytokines. Nat. Immunol. 13:925-931.

Bannerman, D. D., M. Rinaldi, B. T. Vinyard, J. Laihia, and L. Leino. 2009. Effects of intramammary infusion of cis-urocanic acid on mastitis-associated inflammation and tissue injury in dairy cows. Am. J. Vet. Res. 70:373-382.

Begriche, K., A. Igoudjil, D. Pessayre, and B. Fromenty. 2006. Mitochondrial dysfunction in NASH: Causes, consequences and possible means to prevent it. Mitochondrion 6:1-28.

Bell, A. W. 1995. Regulation of organic nutrient metabolism during transition from late pregnancy to early lactation. J. Anim. Sci. 73:2804-2819.

Bernabucci, U., B. Ronchi, N. Lacetera, and A. Nardone. 2005. Influence of body condition score on relationships between metabolic 
status and oxidative stress in periparturient dairy cows. J. Dairy Sci. 88:2017-2026

Bertoni, G., A. Minuti, and E. Trevisi. 2015. Immune system, inflammation and nutrition in dairy cattle. Anim. Prod. Sci. 55:943948. http://dx.doi.org/10.1071/AN14863.

Bertoni, G., E. Trevisi, X. Han, and M. Bionaz. 2008. Effects of inflammatory conditions on liver activity in puerperium period and consequences for performance in dairy cows. J. Dairy Sci 91:3300-3310.

Bertoni, G., E. Trevisi, and F. Piccioli-Cappelli. 2004. Effects of acetyl-salicylate used in post-calving of dairy cows. Vet. Res. Commun. 28:217-219.

Bionaz, M., E. Trevisi, L. Calamari, F. Librandi, A. Ferrari, and G. Bertoni. 2007. Plasma paraoxonase, health, inflammatory conditions, and liver function in transition dairy cows. J. Dairy Sci. 90:1740-1750

Bonilla, D. L., Y. Y. Fan, R. S. Chapkin, and D. N. McMurray. 2010. Transgenic mice enriched in omega-3 fatty acids are more susceptible to pulmonary tuberculosis: Impaired resistance to tuberculosis in fat-1 mice. J. Infect. Dis. 201:399-408.

Boro, P., A. Kumaresan, A. K. Singh, D. Gupta, S. Kumar, A. Manimaran, A. K. Mohanty, T. K. Mohanty, R. Pathak, N. M. Attupuram, R. K. Baithalu, and S. Prasad. 2014. Expression of short chain fatty acid receptors and pro-inflammatory cytokines in utero-placental tissues is altered in cows developing retention of fetal membranes. Placenta 35:455-460.

Bourne, N., R. Laven, D. C. Wathes, T. Martinez, and M. McGowan. 2007. A meta-analysis of the effects of vitamin E supplementation on the incidence of retained foetal membranes in dairy cows. Theriogenology 67:494-501.

Bradford, B. J., L. K. Mamedova, J. E. Minton, J. S. Drouillard, and B. J. Johnson. 2009. Daily injection of tumor necrosis factor- $\alpha$ increases hepatic triglycerides and alters transcript abundance of metabolic genes in lactating dairy cattle. J. Nutr. 139:1451-1456.

Calay, E. S., and G. S. Hotamisligil. 2013. Turning off the inflammatory, but not the metabolic, flames. Nat. Med. 19:265-267.

Cao, Y., G. Bonizzi, T. N. Seagroves, F. R. Greten, R. Johnson, E. V. Schmidt, and M. Karin. 2001. IKK $\alpha$ provides an essential link between RANK signaling and cyclin D1 expression during mammary gland development. Cell 107:763-775.

Ceciliani, F., J. J. Ceron, P. D. Eckersall, and H. Sauerwein. 2012 Acute phase proteins in ruminants. J. Proteomics 75:4207-4231.

Challis, J. R., C. J. Lockwood, L. Myatt, J. E. Norman, J. F. Strauss, and F. Petraglia. 2009. Inflammation and pregnancy. Reprod. Sci. 16:206-215.

Chida, Y., N. Sudo, and C. Kubo. 2006. Does stress exacerbate liver diseases? J. Gastroenterol. Hepatol. 21:202-208.

Cinti, S., G. Mitchell, G. Barbatelli, I. Murano, E. Ceresi, E. Faloia, S. Wang, M. Fortier, A. S. Greenberg, and M. S. Obin. 2005. Adipocyte death defines macrophage localization and function in adipose tissue of obese mice and humans. J. Lipid Res. 46:2347-2355.

Coetzee, J. F., R. Gehring, A. C. Bettenhausen, B. V. Lubbers, S. E Toerber, D. U. Thomson, B. Kukanich, and M. D. Apley. 2007. Attenuation of acute plasma cortisol response in calves following intravenous sodium salicylate administration prior to castration. J. Vet. Pharmacol. Ther. 30:305-313.

Contreras, G. A., W. Raphael, S. A. Mattmiller, J. Gandy, and L. M. Sordillo. 2012. Nonesterified fatty acids modify inflammatory response and eicosanoid biosynthesis in bovine endothelial cells. J. Dairy Sci. 95:5011-5023.

Coussens, L. M., and Z. Werb. 2002. Inflammation and cancer. Nature 420:860-867.

Damian, P., A. L. Craigmill, and J. E. Riviere. 1997. Extralabel use of nonsteroidal anti-inflammatory drugs. J. Am. Vet. Med. Assoc. 211:860-861.

Dantzer, R., and K. W. Kelley. 2007. Twenty years of research on cytokine-induced sickness behavior. Brain Behav. Immun. 21:153-160.

Darling, N. J., and S. J. Cook. 2014. The role of MAPK signalling pathways in the response to endoplasmic reticulum stress. Biochim. Biophys. Acta 1843:2150-2163.
Dehbi, M., T. Uzzaman, E. Baturcam, A. Eldali, W. Ventura, and A. Bouchama. 2012. Toll-like receptor 4 and high-mobility group box 1 are critical mediators of tissue injury and survival in a mouse model for heatstroke. PLoS ONE 7:e44100.

Depke, M., L. Steil, G. Domanska, U. Völker, C. Schütt, and C. Kiank. 2009. Altered hepatic mRNA expression of immune response and apoptosis-associated genes after acute and chronic psychological stress in mice. Mol. Immunol. 46:3018-3028.

DiAngelo, J. R., M. L. Bland, S. Bambina, S. Cherry, and M. J. Birnbaum. 2009. The immune response attenuates growth and nutrient storage in Drosophila by reducing insulin signaling. Proc. Natl. Acad. Sci. USA 106:20853-20858.

DiSilvestro, R. A. 1986. Plasma levels of immunoreactive ceruloplasmin and other acute phase proteins during lactation. Proc. Soc. Exp. Biol. Med. 183:257-261.

Drackley, J. K. 1999. ADSA Foundation Scholar Award. Biology of dairy cows during the transition period: The final frontier? J. Dairy Sci. 82:2259-2273.

Drillich, M., D. Voigt, D. Forderung, and W. Heuwieser. 2007. Treatment of acute puerperal metritis with flunixin meglumine in addition to antibiotic treatment. J. Dairy Sci. 90:3758-3763.

Dubuc, J., T. F. Duffield, K. E. Leslie, J. S. Walton, and S. J. LeBlanc. 2010. Risk factors for postpartum uterine diseases in dairy cows. J. Dairy Sci. 93:5764-5771.

Duffield, T. F., H. Putnam-Dingwell, D. Weary, A. Skidmore, L. Neuder, W. Raphael, S. Millman, N. Newby, and K. E. Leslie. 2009 Effect of flunixin meglumine treatment following parturition on cow health and milk production. J. Dairy Sci. 92(E-Suppl. 1):117. (Abstr.)

Elsasser, T. H., T. J. Caperna, C. J. Li, S. Kahl, and J. L. Sartin. 2008. Critical control points in the impact of the proinflammatory immune response on growth and metabolism. J. Anim. Sci. 86:E105-E125.

Emmanuel, D. G. V., S. M. Dunn, and B. N. Ametaj. 2008. Feeding high proportions of barley grain stimulates an inflammatory response in dairy cows. J. Dairy Sci. 91:606-614.

Farney, J. K., L. K. Mamedova, J. F. Coetzee, B. KuKanich, L. M. Sordillo, S. K. Stoakes, J. E. Minton, L. C. Hollis, and B. J. Bradford. 2013a. Anti-inflammatory salicylate treatment alters the metabolic adaptations to lactation in dairy cattle. Am. J. Physiol. Regul. Integr. Comp. Physiol. 305:R110-R117.

Farney, J. K., L. K. Mamedova, J. F. Coetzee, J. E. Minton, L. C Hollis, and B. J. Bradford. 2013b. Sodium salicylate treatment in early lactation increases whole-lactation milk and milk fat yield in mature dairy cows. J. Dairy Sci. 96:7709-7718.

Fiorentino, D. F., A. Zlotnik, T. R. Mosmann, M. Howard, and A. O'Garra. 1991. IL-10 inhibits cytokine production by activated macrophages. J. Immunol. 147:3815-3822.

Galloway, E., T. Shin, N. Huber, T. Eismann, S. Kuboki, R. Schuster, J. Blanchard, H. R. Wong, and A. B. Lentsch. 2008. Activation of hepatocytes by extracellular heat shock protein 72 . Am. J. Physiol. Cell Physiol. 295:C514-C520.

Garlanda, C., C. A. Dinarello, and A. Mantovani. 2013. The interleukin-1 family: Back to the future. Immunity 39:1003-1018.

Gessner, D. K., G. Schlegel, J. Keller, F. J. Schwarz, R. Ringseis, and K. Eder. 2013. Expression of target genes of nuclear factor E2related factor 2 in the liver of dairy cows in the transition period and at different stages of lactation. J. Dairy Sci. 96:1038-1043.

Gingerich, D. A., J. D. Baggot, and R. A. Yeary. 1975. Pharmacokinetics and dosage of aspirin in cattle. J. Am. Vet. Med. Assoc. 167:945-948.

Glass, C. K., and K. Saijo. 2010. Nuclear receptor transrepression pathways that regulate inflammation in macrophages and $\mathrm{T}$ cells. Nat. Rev. Immunol. 10:365-376.

Goff, J. P. 2006. Major advances in our understanding of nutritional influences on bovine health. J. Dairy Sci. 89:1292-1301.

Gott, P. N., J. S. Hogan, and W. P. Weiss. 2015. Effects of various starch feeding regimens on responses of dairy cows to intramammary lipopolysaccharide infusion. J. Dairy Sci. 98:1786-1796. 
Grant, R. J., and J. L. Albright. 1995. Feeding behavior and management factors during the transition period in dairy cattle. J. Anim. Sci. 73:2791-2803.

Graugnard, D. E., M. Bionaz, E. Trevisi, K. M. Moyes, J. L. SalakJohnson, R. L. Wallace, J. K. Drackley, G. Bertoni, and J. J. Loor. 2012. Blood immunometabolic indices and polymorphonuclear neutrophil function in peripartum dairy cows are altered by level of dietary energy prepartum. J. Dairy Sci. 95:1749-1758.

Greco, L. F., J. T. N. Neto, A. Pedrico, R. A. Ferrazza, F. S. Lima, R. S. Bisinotto, N. Martinez, M. Garcia, E. S. Ribeiro, G. C. Gomes, J. H. Shin, M. A. Ballou, W. W. Thatcher, C. R. Staples, and J. E. P. Santos. 2015. Effects of altering the ratio of dietary n- 6 to n-3 fatty acids on performance and inflammatory responses to a lipopolysaccharide challenge in lactating Holstein cows. J. Dairy Sci. 98:602-617.

Gregor, M. F., and G. S. Hotamisligil. 2011. Inflammatory mechanisms in obesity. Annu. Rev. Immunol. 29:415-445.

Gregor, M. F., E. S. Misch, L. Yang, S. Hummasti, K. E. Inouye, A. H. Lee, B. Bierie, and G. S. Hotamisligil. 2013. The role of adipocyte XBP1 in metabolic regulation during lactation. Cell Reports 3:1430-1439.

Grum, D. E., J. K. Drackley, R. S. Younker, D. W. LaCount, and J. J. Veenhuizen. 1996. Nutrition during the dry period and hepatic lipid metabolism of periparturient dairy cows. J. Dairy Sci. 79:1850-1864.

Hardwick, J. P., K. Eckman, Y. K. Lee, M. A. Abdelmegeed, A. Esterle, W. M. Chilian, J. Y. Chiang, and B. J. Song. 2013. Eicosanoids in metabolic syndrome. Adv. Pharmacol. 66:157-266.

Hawley, S. A., M. D. Fullerton, F. A. Ross, J. D. Schertzer, C. Chevtzoff, K. J. Walker, M. W. Peggie, D. Zibrova, K. A. Green, K. J. Mustard, B. E. Kemp, K. Sakamoto, G. R. Steinberg, and D. G. Hardie. 2012. The ancient drug salicylate directly activates AMPactivated protein kinase. Science 336:918-922.

Hoeben, D., C. Burvenich, E. Trevisi, G. Bertoni, J. Hamann, R. Buckmaier, and J. W. Blum. 2000. Role of endotoxin and TNFalpha in the pathogenesis of experimentally induced coliform mastitis in periparturient cows. J. Dairy Res. 67:503-514.

Hoffmann, A., and D. Baltimore. 2006. Circuitry of nuclear factor $\kappa \mathrm{B}$ signaling. Immunol. Rev. 210:171-186.

Hogan, J., and K. L. Smith. 2003. Coliform mastitis. Vet. Res. 34:507-519.

Holtenius, P., and K. Holtenius. 2007. A model to estimate insulin sensitivity in dairy cows. Acta Vet. Scand. 49:29.

Hotamisligil, G. S. 2006. Inflammation and metabolic disorders. Nature 444:860-867.

Humblet, M.-F., H. Guyot, B. Boudry, F. Mbayahi, C. Hanzen, F. Rollin, and J.-M. Godeau. 2006. Relationship between haptoglobin, serum amyloid $\mathrm{A}$, and clinical status in a survey of dairy herds during a 6-month period. Vet. Clin. Pathol. 35:188-193.

Huzzey, J. M., T. F. Duffield, S. J. LeBlanc, D. M. Veira, D. M. Weary, and M. A. G. von Keyserlingk. 2009. Short communication: Haptoglobin as an early indicator of metritis. J. Dairy Sci. 92:621-625.

Huzzey, J. M., D. V. Nydam, R. J. Grant, and T. R. Overton. 2012. Association of biomarkers of stress, inflammation, and negative energy balance with milk yield and reproductive performance in Holstein dairy cows. J. Dairy Sci. 95(Suppl. 2):705. (Abstr.)

Huzzey, J. M., M. A. von Keyserlingk, and D. M. Weary. 2005. Changes in feeding, drinking, and standing behavior of dairy cows during the transition period. J. Dairy Sci. 88:2454-2461.

Imoto, K., D. Kukidome, T. Nishikawa, T. Matsuhisa, K. Sonoda, K. Fujisawa, M. Yano, H. Motoshima, T. Taguchi, K. Tsuruzoe, T. Matsumura, H. Ichijo, and E. Araki. 2006. Impact of mitochondrial reactive oxygen species and apoptosis signal-regulating kinase 1 on insulin signaling. Diabetes 55:1197-1204.

Ingvartsen, K. L. 2006. Feeding- and management-related diseases in the transition cow: Physiological adaptations around calving and strategies to reduce feeding-related diseases. Anim. Feed Sci. Technol. 126:175-213.

Ishikawa, Y., K. Nakada, K. Hagiwara, R. Kirisawa, H. Iwai, M. Moriyoshi, and Y. Sawamukai. 2004. Changes in interleukin-6 concentration in peripheral blood of pre- and post-partum dairy cattle and its relationship to postpartum reproductive diseases. J. Vet. Med. Sci. 66:1403-1408.

Ji, P., J. K. Drackley, M. J. Khan, and J. J. Loor. 2014. Inflammationand lipid metabolism-related gene network expression in visceral and subcutaneous adipose depots of Holstein cows. J. Dairy Sci. 97:3441-3448.

Ji, R., C. M. Sanchez, C. L. Chou, X. B. Chen, D. F. Woodward, and J. W. Regan. 2012. Prostanoid EP(1) receptors mediate up-regulation of the orphan nuclear receptor Nurr1 by cAMP-independent activation of protein kinase A, CREB and NF-kappaB. Br. J. Pharmacol. 166:1033-1046.

Kern, P. A., S. Ranganathan, C. Li, L. Wood, and G. Ranganathan. 2001. Adipose tissue tumor necrosis factor and interleukin-6 expression in human obesity and insulin resistance. Am. J. Physiol. Endocrinol. Metab. 280:E745-E751.

Kopp, E., and S. Ghosh. 1994. Inhibition of NF-kappa B by sodium salicylate and aspirin. Science 265:956-959.

Kozak, W., H. Zheng, C. A. Conn, D. Soszynski, L. H. van der Ploeg, and M. J. Kluger. 1995. Thermal and behavioral effects of lipopolysaccharide and influenza in interleukin-1 beta-deficient mice. Am. J. Physiol. 269:R969-R977.

Kuhla, B., G. Nurnberg, D. Albrecht, S. Gors, H. M. Hammon, and C. C. Metges. 2011. Involvement of skeletal muscle protein, glycogen, and fat metabolism in the adaptation on early lactation of dairy cows. J. Proteome Res. 10:4252-4262.

Kushibiki, S., K. Hodate, H. Shingu, Y. Obara, E. Touno, M. Shinoda, and Y. Yokomizo. 2003. Metabolic and lactational responses during recombinant bovine tumor necrosis factor- $\alpha$ treatment in lactating cows. J. Dairy Sci. 86:819-827.

LeBlanc, S. J., T. H. Herdt, W. M. Seymour, T. F. Duffield, and K. E. Leslie. 2004. Peripartum serum vitamin E, retinol, and betacarotene in dairy cattle and their associations with disease. J. Dairy Sci. 87:609-619.

LeBlanc, S. J., T. Osawa, and J. Dubuc. 2011. Reproductive tract defense and disease in postpartum dairy cows. Theriogenology 76:1610-1618.

Lessard, M., N. Gagnon, and H. V. Petit. 2003. Immune response of postpartum dairy cows fed flaxseed. J. Dairy Sci. 86:2647-2657.

Lewis, R. B., and J. Schulman. 1973. Influence of acetylsalicylic acid, an inhibitor of prostaglandin synthesis, on the duration of human gestation and labour. Lancet 302:1159-1161.

Liu, M., K. Saeki, T. Matsunobu, T. Okuno, T. Koga, Y. Sugimoto, C. Yokoyama, S. Nakamizo, K. Kabashima, S. Narumiya, T. Shimizu, and T. Yokomizo. 2014. 12-hydroxyheptadecatrienoic acid promotes epidermal wound healing by accelerating keratinocyte migration via the BLT2 receptor. J. Exp. Med. 211:1063-1078.

Lomax, M. A., and G. D. Baird. 1983. Blood flow and nutrient exchange across the liver and gut of the dairy cow. Br. J. Nutr. 49:481-496.

Loor, J. J. 2010. Genomics of metabolic adaptations in the peripartal cow. Animal 4:1110-1139.

Loor, J. J., H. M. Dann, R. E. Everts, R. Oliveira, C. A. Green, N. A. J. Guretzky, S. L. Rodriguez-Zas, H. A. Lewin, and J. K. Drackley. 2005. Temporal gene expression profiling of liver from periparturient dairy cows reveals complex adaptive mechanisms in hepatic function. Physiol. Genomics 23:217-226.

Maitra, U., L. Gan, S. Chang, and L. Li. 2011. Low-dose endotoxin induces inflammation by selectively removing nuclear receptors and activating CCAAT/enhancer-binding protein delta. J. Immunol. 186:4467-4473.

Mallard, B. A., J. C. Dekkers, M. J. Ireland, K. E. Leslie, S. Sharif, C. L. Vankampen, L. Wagter, and B. N. Wilkie. 1998. Alteration in immune responsiveness during the peripartum period and its ramification on dairy cow and calf health. J. Dairy Sci. 81:585-595.

Malley, R., P. Henneke, S. C. Morse, M. J. Cieslewicz, M. Lipsitch, C. M. Thompson, E. Kurt-Jones, J. C. Paton, M. R. Wessels, and D. T. Golenbock. 2003. Recognition of pneumolysin by toll-like receptor 4 confers resistance to pneumococcal infection. Proc. Natl. Acad. Sci. USA 100:1966-1971.

Mamedova, L. K., K. Yuan, A. N. Laudick, S. D. Fleming, D. G. Mashek, and B. J. Bradford. 2013. Toll-like receptor 4 signal- 
ing is required for induction of gluconeogenic gene expression by palmitate in human hepatic carcinoma cells. J. Nutr. Biochem. 24:1499-1507.

Mao, G., G. A. Kraus, I. Kim, M. E. Spurlock, T. B. Bailey, Q. Zhang, and D. C. Beitz. 2010. A mitochondria-targeted vitamin E derivative decreases hepatic oxidative stress and inhibits fat deposition in mice. J. Nutr. 140:1425-1431.

Marques, R. S., R. F. Cooke, C. L. Francisco, and D. W. Bohnert. 2012. Effects of twenty-four hour transport or twenty-four hour feed and water deprivation on physiologic and performance responses of feeder cattle. J. Anim. Sci. 90:5040-5046.

Martel, C. A., L. K. Mamedova, J. E. Minton, M. L. Jones, J. A. Carroll, and B. J. Bradford. 2014. Continuous low-dose infusion of tumor necrosis factor alpha in adipose tissue elevates adipose tissue interleukin 10 abundance and fails to alter metabolism in lactating dairy cows. J. Dairy Sci. 97:4897-4906.

McDougall, S., M. A. Bryan, and R. M. Tiddy. 2009. Effect of treatment with the nonsteroidal antiinflammatory meloxicam on milk production, somatic cell count, probability of re-treatment, and culling of dairy cows with mild clinical mastitis. J. Dairy Sci. 92:4421-4431

McNamara, J. P. 2012. Ruminant Nutrition Symposium: A systems approach to integrating genetics, nutrition, and metabolic efficiency in dairy cattle. J. Anim. Sci. 90:1846-1854.

Medzhitov, R. 2008. Origin and physiological roles of inflammation. Nature 454:428-435.

Meier, S., N. V. Priest, C. R. Burke, J. K. Kay, S. McDougall, M. D. Mitchell, C. G. Walker, A. Heiser, J. J. Loor, and J. R. Roche. 2014. Treatment with a nonsteroidal antiinflammatory drug after calving did not improve milk production, health, or reproduction parameters in pasture-grazed dairy cows. J. Dairy Sci. 97:29322943.

Mireles, A. J., S. M. Kim, and K. C. Klasing. 2005. An acute inflammatory response alters bone homeostasis, body composition, and the humoral immune response of broiler chickens. Poult. Sci. $84: 553-560$.

Monteiro, R., and I. Azevedo. 2010. Chronic inflammation in obesity and the metabolic syndrome. Mediators Inflamm. 2010:289645.

Morkoc, A. C., W. L. Hurley, H. L. Whitmore, and B. K. Gustafsson. 1993. Bovine acute mastitis: Effects of intravenous sodium salicylate on endotoxin-induced intramammary inflammation. J. Dairy Sci. 76:2579-2588

Morrow, D. A. 1976. Fat cow syndrome. J. Dairy Sci. 59:1625-1629.

Mudron, P., J. Rehage, H. P. Sallmann, M. Mertens, H. Scholz, and G. Kovac. 1997. Plasma and liver alpha-tocopherol in dairy cows with left abomasal displacement and fatty liver. Zentralbl. Veterinarmed. A 44:91-97.

Mudron, P., J. Rehage, K. Qualmann, H. P. Sallmann, and H. Scholz. 1999. A study of lipid peroxidation and vitamin $\mathrm{E}$ in dairy cows with hepatic insufficiency. Zentralbl. Veterinarmed. A 46:219 224 .

Mullins, C. R., L. K. Mamedova, M. J. Brouk, C. E. Moore, H. B. Green, K. L. Perfield, J. F. Smith, J. P. Harner, and B. J. Bradford. 2012. Effects of monensin on metabolic parameters, feeding behavior, and productivity of transition dairy cows. J. Dairy Sci. 95:1323-1336

Nakamura, K. 2011. Central circuitries for body temperature regulation and fever. Am. J. Physiol. Regul. Integr. Comp. Physiol. 301:R1207-R1228.

Nathan, C., and A. Ding. 2010. Nonresolving inflammation. Cel 140:871-882

Newby, N. C., D. Renaud, R. Tremblay, and T. Duffield. 2014. Evaluation of the effects of treating dairy cows with meloxicam at calving on retained fetal membranes risk. Can. Vet. J. 55:1196-1199.

Newby, N. C., D. L. Pearl, S. J. LeBlanc, K. E. Leslie, M. A. G. von Keyserlingk, and T. F. Duffield. 2013. Effects of meloxicam on milk production, behavior, and feed intake in dairy cows following assisted calving. J. Dairy Sci. 96:3682-3688.

Newton, K., and V. M. Dixit. 2012. Signaling in innate immunity and inflammation. Cold Spring Harb. Perspect. Biol. 4:a006049.
Nightingale, C. R., M. D. Sellers, and M. A. Ballou. 2015. Elevated plasma haptoglobin concentrations following parturition are associated with elevated leukocyte responses and decreased subsequent reproductive efficiency in multiparous Holstein dairy cows. Vet. Immunol. Immunopathol. 164:16-23.

Nørgaard, J. V., P. K. Theil, M. T. Sørensen, and K. Sejrsen. 2008 Cellular mechanisms in regulating mammary cell turnover during lactation and dry period in dairy cows. J. Dairy Sci. 91:2319 2327

Odegaard, J. I., and A. Chawla. 2012. Leukocyte set points in metabolic disease. F1000 Biol. Rep. 4:13.

Odegaard, J. I., and A. Chawla. 2013. Pleiotropic actions of insulin resistance and inflammation in metabolic homeostasis. Science 339:172-177.

Ohtsuka, H., M. Koiwa, A. Hatsugaya, K. Kudo, F. Hoshi, N. Itoh, H. Yokota, H. Okada, and S. Kawamura. 2001. Relationship between serum TNF activity and insulin resistance in dairy cows affected with naturally occurring fatty liver. J. Vet. Med. Sci. 63:1021-1025

Pearce, S. C., V. Mani, T. E. Weber, R. P. Rhoads, J. F. Patience, L. H. Baumgard, and N. K. Gabler. 2013. Heat stress and reduced plane of nutrition decreases intestinal integrity and function in pigs. J. Anim. Sci. 91:5183-5193.

Petzl, W., J. Gunther, T. Pfister, C. Sauter-Louis, L. Goetze, S. von Aulock, A. Hafner-Marx, H. J. Schuberth, H. M. Seyfert, and H. Zerbe. 2012. Lipopolysaccharide pretreatment of the udder protects against experimental Escherichia coli mastitis. Innate Immun. 18:467-477.

Pfeffer, K., T. Matsuyama, T. M. Kundig, A. Wakeham, K. Kishihara, A. Shahinian, K. Wiegmann, P. S. Ohashi, M. Kronke, and T. W. Mak. 1993. Mice deficient for the $55 \mathrm{kd}$ tumor necrosis factor receptor are resistant to endotoxic shock, yet succumb to L. monocytogenes infection. Cell 73:457-467.

Pierce, J. W., M. A. Read, H. Ding, F. W. Luscinskas, and T. Col lins. 1996. Salicylates inhibit I kappa B-alpha phosphorylation, endothelial-leukocyte adhesion molecule expression, and neutrophil transmigration. J. Immunol. 156:3961-3969.

Politis, I. 2012. Reevaluation of vitamin E supplementation of dairy cows: Bioavailability, animal health and milk quality. Animal http://dx.doi.org/http://dx.doi.org/10.1017/S1751731112000225.

Priest, N. V., S. McDougall, C. R. Burke, J. R. Roche, M. Mitchell, K. L. McLeod, S. L. Greenwood, and S. Meier. 2013. The responsiveness of subclinical endometritis to a nonsteroidal antiinflammatory drug in pasture-grazed dairy cows. J. Dairy Sci. 96:4323-4332.

Qu, Y. A. N. Fadden, M. G. Traber, and G. Bobe. 2014. Potential risk indicators of retained placenta and other diseases in multiparous cows. J. Dairy Sci. 97:4151-4165.

Ringseis, R., D. K. Gessner, and K. Eder. 2015. Molecular insights into the mechanisms of liver-associated diseases in early-lactating dairy cows: Hypothetical role of endoplasmic reticulum stress. J. Anim. Physiol. Anim. Nutr. 99:626-645. http://dx.doi.org/10.1111/ jpn.12263.

Rosenbaum, S., R. Ringseis, S. Hillen, S. Becker, G. Erhardt, G. Reiner, and K. Eder. 2012a. Genome-wide transcript profiling indicates induction of energy-generating pathways and an adaptive immune response in the liver of sows during lactation. Comp. Biochem. Physiol. D Genomics Proteomics 7:370-381.

Rosenbaum, S., R. Ringseis, S. Hillen, S. Becker, G. Erhardt, G. Reiner, and K. Eder. 2012b. The stress signalling pathway nuclear factor E2-related factor 2 is activated in the liver of sows during lactation. Acta Vet. Scand. 54:59.

Sadri, H., R. M. Bruckmaier, H. R. Rahmani, G. R. Ghorbani, I. Morel, and H. A. Van Dorland. 2010. Gene expression of tumour necrosis factor and insulin signalling-related factors in subcutaneous adipose tissue during the dry period and in early lactation in dairy cows. J. Anim. Physiol. Anim. Nutr. (Berl.) 94:e194-e202.

Sakaguchi, S., and S. Furusawa. 2006. Oxidative stress and septic shock: metabolic aspects of oxygen-derived free radicals generated in the liver during endotoxemia. FEMS Immunol. Med. Microbiol. 47:167-177. 
Sanyal, A. J., N. Chalasani, K. V. Kowdley, A. McCullough, A. M. Diehl, N. M. Bass, B. A. Neuschwander-Tetri, J. E. Lavine, J. Tonascia, A. Unalp, M. Van Natta, J. Clark, E. M. Brunt, D. E. Kleiner, J. H. Hoofnagle, and P. R. Robuck. 2010. Pioglitazone, vitamin E, or placebo for nonalcoholic steatohepatitis. N. Engl. J. Med. 362:1675-1685.

Saremi, B., A. Al-Dawood, S. Winand, U. Muller, J. Pappritz, D. von Soosten, J. Rehage, S. Danicke, S. Haussler, M. Mielenz, and H. Sauerwein. 2012. Bovine haptoglobin as an adipokine: Serum concentrations and tissue expression in dairy cows receiving a conjugated linoleic acids supplement throughout lactation. Vet. Immunol. Immunopathol. 146:201-211.

Schoenberg, K. M., K. L. Perfield, J. K. Farney, B. J. Bradford, Y. R. Boisclair, and T. R. Overton. 2011. Effects of prepartum 2,4-thiazolidinedione on insulin sensitivity, plasma concentrations of tumor necrosis factor- $\alpha$ and leptin, and adipose tissue gene expression. J. Dairy Sci. 94:5523-5532.

Schukken, Y. H., J. Gunther, J. Fitzpatrick, M. C. Fontaine, L. Goetze, O. Holst, J. Leigh, W. Petzl, H. J. Schuberth, A. Sipka, D. G. Smith, R. Quesnell, J. Watts, R. Yancey, H. Zerbe, A. Gurjar, R. N. Zadoks, and H. M. Seyfert., and members of the Pfizer mastitis research consortium. 2011. Host-response patterns of intramammary infections in dairy cows. Vet. Immunol. Immunopathol. 144:270-289.

Seki, E., D. A. Brenner, and M. Karin. 2012. A liver full of JNK: Signaling in regulation of cell function and disease pathogenesis, and clinical approaches. Gastroenterology 143:307-320.

Serhan, C. N. 2011. The resolution of inflammation: The devil in the flask and in the details. FASEB J. 25:1441-1448.

Shwartz, G., K. L. Hill, M. J. VanBaale, and L. H. Baumgard. 2009. Effects of flunixin meglumine on pyrexia and bioenergetic variables in postparturient dairy cows. J. Dairy Sci. 92:1963-1970.

Silva, P. R., J. G. Moraes, L. G. Mendonca, A. A. Scanavez, G. Nakagawa, J. Fetrow, M. I. Endres, and R. C. Chebel. 2013. Effects of weekly regrouping of prepartum dairy cows on metabolic, health, reproductive, and productive parameters. J. Dairy Sci. 96:4436-4446.

Silvestre, F. T., T. S. M. Carvalho, P. C. Crawford, J. E. P. Santos, C. R. Staples, T. Jenkins, and W. W. Thatcher. 2011. Effects of differential supplementation of fatty acids during the peripartum and breeding periods of Holstein cows: II. Neutrophil fatty acids and function, and acute phase proteins. J. Dairy Sci. 94:2285-2301.

Singh, K., A. J. Molenaar, K. M. Swanson, B. Gudex, J. A. Arias, R. A. Erdman, and K. Stelwagen. 2012. Epigenetics: A possible role in acute and transgenerational regulation of dairy cow milk production. Animal 6:375-381.

Smith, K. L., J. H. Harrison, D. D. Hancock, D. A. Todhunter, and H. R. Conrad. 1984. Effect of vitamin E and selenium supplementation on incidence of clinical mastitis and duration of clinical symptoms. J. Dairy Sci. 67:1293-1300.

Sonti, G., S. E. Ilyin, and C. R. Plata-Salaman. 1996. Anorexia induced by cytokine interactions at pathophysiological concentrations. Am. J. Physiol. 270:R1394-R1402.

Sordillo, L. M., G. A. Contreras, and S. L. Aitken. 2009. Metabolic factors affecting the inflammatory response of periparturient dairy cows. Anim. Health Res. Rev. 10:53-63.

Sordillo, L. M., G. M. Pighetti, and M. R. Davis. 1995. Enhanced production of bovine tumor necrosis factor-alpha during the periparturient period. Vet. Immunol. Immunopathol. 49:263-270.

Sordillo, L. M., and K. L. Streicher. 2002. Mammary gland immunity and mastitis susceptibility. J. Mammary Gland Biol. Neoplasia 7:135-146.

Spite, M., J. Claria, and C. N. Serhan. 2014. Resolvins, specialized proresolving lipid mediators, and their potential roles in metabolic diseases. Cell Metab. 19:21-36.

Steeneveld, W., H. Hogeveen, H. W. Barkema, J. van den Broek, and R. B. Huirne. 2008. The influence of cow factors on the incidence of clinical mastitis in dairy cows. J. Dairy Sci. 91:1391-1402.

Sugimoto, Y., A. Yamasaki, E. Segi, K. Tsuboi, Y. Aze, T. Nishimura, H. Oida, N. Yoshida, T. Tanaka, M. Katsuyama, K.-y. Hasumoto, T. Murata, M. Hirata, F. Ushikubi, M. Negishi, A. Ichikawa, and
S. Narumiya. 1997. Failure of parturition in mice lacking the prostaglandin F receptor. Science 277:681-683.

Sung, M. H., N. Li, Q. Lao, R. A. Gottschalk, G. L. Hager, and I. D. Fraser. 2014. Switching of the relative dominance between feedback mechanisms in lipopolysaccharide-induced NF-kappaB signaling. Sci. Signal. 7:ra6.

Takeuchi, O., and S. Akira. 2010. Pattern recognition receptors and inflammation. Cell 140:805-820.

Tang, T., J. Zhang, J. Yin, J. Staszkiewicz, B. Gawronska-Kozak, D. Y. Jung, H. J. Ko, H. Ong, J. K. Kim, R. Mynatt, R. J. Martin, M. Keenan, Z. Gao, and J. Ye. 2010. Uncoupling of inflammation and insulin resistance by NF-kB in transgenic mice through elevated energy expenditure. J. Biol. Chem. 285:4637-4644.

Tao, S., E. E. Connor, J. W. Bubolz, I. M. Thompson, B. C. do Amaral, M. J. Hayen, and G. E. Dahl. 2013. Short communication: Effect of heat stress during the dry period on gene expression in mammary tissue and peripheral blood mononuclear cells. J. Dairy Sci. 96:378-383.

Tegeder, I., J. Pfeilschifter, and G. Geisslinger. 2001. Cyclooxygenase-independent actions of cyclooxygenase inhibitors. FASEB J. 15:2057-2072.

Tilg, H., and A. R. Moschen. 2010. Evolution of inflammation in nonalcoholic fatty liver disease: The multiple parallel hits hypothesis. Hepatology 52:1836-1846.

Tisoncik, J. R., M. J. Korth, C. P. Simmons, J. Farrar, T. R. Martin, and M. G. Katze. 2012. Into the eye of the cytokine storm. Microbiol. Mol. Biol. Rev. 76:16-32.

Trevisi, E., M. Amadori, A. M. Bakudila, and G. Bertoni. 2009. Metabolic changes in dairy cows induced by oral, low-dose interferonalpha treatment. J. Anim. Sci. 87:3020-3029.

Trevisi, E., and G. Bertoni. 2008. Attenuation with acetylsalicylate treatments of inflammatory conditions in periparturient dairy cows. Pages $22-37$ in Aspirin and Health Research Progress. P. I. Quinn, ed. Nova Science Publishers, Hauppauge, NY.

USDA. 2009. NAHMS Dairy 2007 Part V: Changes in Dairy Cattle Health and Management Practices in the United States, 19962007. USDA, Washington, DC.

VallerieS.HotamisligilG. 2010. The role of JNK proteins in metabolism. Sci. Transl. Med. 2:60rv65.

van Engelen, E., M. W. de Groot, V. N. Breeveld-Dwarkasing, M. E. Everts, G. C. van der Weyden, M. A. Taverne, and V. P. Rutten. 2009. Cervical ripening and parturition in cows are driven by a cascade of pro-inflammatory cytokines. Reprod. Domest. Anim. 44:834-841.

Vangroenweghe, F., L. Duchateau, P. Boutet, P. Lekeux, P. Rainard, M. J. Paape, and C. Burvenich. 2005. Effect of carprofen treatment following experimentally induced Escherichia coli mastitis in primiparous cows. J. Dairy Sci. 88:2361-2376.

Virkamäki, A., and H. Yki-Järvinen. 1995. Role of prostaglandins in mediating alterations in glucose metabolism during acute endotoxemia in the rat. Endocrinology 136:1701-1706.

von Soosten, D., U. Meyer, M. Piechotta, G. Flachowsky, and S. Danicke. 2012. Effect of conjugated linoleic acid supplementation on body composition, body fat mobilization, protein accretion, and energy utilization in early lactation dairy cows. J. Dairy Sci. 95:1222-1239.

Vorbach, C., M. R. Capecchi, and J. M. Penninger. 2006. Evolution of the mammary gland from the innate immune system? BioEssays $28: 606-616$.

Waelchli, R. O., R. Thun, and H. Stocker. 1999. Effect of flunixin meglumine on placental expulsion in dairy cattle after a caesarean. Vet. Rec. 144:702-703.

Waldron, M. R., A. E. Kulick, A. W. Bell, and T. R. Overton. 2006. Acute experimental mastitis is not causal toward the development of energy-related metabolic disorders in early postpartum dairy cows. J. Dairy Sci. 89:596-610.

Watson, C. J. 2009. Immune cell regulators in mouse mammary development and involution. J. Anim. Sci. 87:35-42.

Wei, Y., D. Wang, C. Gentile, and M. Pagliassotti. 2009. Reduced endoplasmic reticulum luminal calcium links saturated fatty acid- 
mediated endoplasmic reticulum stress and cell death in liver cells. Mol. Cell. Biochem. 331:31-40.

Weiss, W. P., J. S. Hogan, K. L. Smith, and K. H. Hoblet. 1990a. Relationships among selenium, vitamin E, and mammary gland health in commercial dairy herds. J. Dairy Sci. 73:381-390.

Weiss, W. P., D. A. Todhunter, J. S. Hogan, and K. L. Smith. 1990b. Effect of duration of supplementation of selenium and vitamin $\mathrm{E}$ on periparturient dairy cows. J. Dairy Sci. 73:3187-3194.

Wernstedt Asterholm, I., C. Tao, T. S. Morley, Q. A. Wang, F. Delgado-Lopez, Z. V. Wang, and P. E. Scherer. 2014. Adipocyte inflammation is essential for healthy adipose tissue expansion and remodeling. Cell Metab. 20:103-118.

Williams, K. I., and J. R. Vane. 1975. Inhibition of uterine motility: The possible role of the prostaglandins and aspirin-like drugs. Pharmacol. Ther. B 1:89-113.

Wolowczuk, I., C. Verwaerde, O. Viltart, A. Delanoye, M. Delacre, B. Pot, and C. Grangette. 2008. Feeding our immune system: Impact on metabolism. Clin. Dev. Immunol. 2008:639803.

Ye, J., and J. N. Keller. 2010. Regulation of energy metabolism by inflammation: A feedback response in obesity and calorie restriction. Aging 2:361-368.

Yoshioka, M., A. Watanabe, N. Shimada, H. Murata, Y. Yokomizo, and Y. Nakajima. 2002. Regulation of haptoglobin secretion by recombinant bovine cytokines in primary cultured bovine hepatocytes. Domest. Anim. Endocrinol. 23:425-433.

Yuan, K., J. K. Farney, L. K. Mamedova, L. M. Sordillo, and B. J. Bradford. 2013. TNFo altered inflammatory responses, impaired health and productivity, but did not affect glucose or lipid metabolism in early-lactation dairy cows. PLoS ONE 8:e80316.

Yuan, K., L. G. D. Mendonca, L. E. Hulbert, L. K. Mamedova, M. B. Muckey, Y. Shen, C. C. Elrod, and B. J. Bradford. 2015. Yeast product supplementation modulated humoral and mucosal immunity and uterine inflammatory signals in transition dairy cows. J. Dairy Sci. 98:3236-3246.

Yuan, M., N. Konstantopoulos, J. Lee, L. Hansen, Z.-W. Li, M. Karin, and S. E. Shoelson. 2001. Reversal of obesity- and diet-induced insulin resistance with salicylates or targeted disruption of Ikkbeta. Science 293:1673-1677.

Zachut, M., H. Honig, S. Striem, Y. Zick, S. Boura-Halfon, and U. Moallem. 2013. Periparturient dairy cows do not exhibit hepatic insulin resistance, yet adipose-specific insulin resistance occurs in cows prone to high weight loss. J. Dairy Sci. 96:5656-5669.

Zebeli, Q., D. Mansmann, S. Sivaraman, S. M. Dunn, and B. N. Ametaj. 2013. Oral challenge with increasing doses of LPS modulated the patterns of plasma metabolites and minerals in periparturient dairy cows. Innate Immun. 19:298-314.

Zhang, F. J., X. G. Weng, J. F. Wang, D. Zhou, W. Zhang, C. C. Zhai, Y. X. Hou, and Y. H. Zhu. 2014. Effects of temperature-humidity index and chromium supplementation on antioxidant capacity, heat shock protein 72 , and cytokine responses of lactating cows. J. Anim. Sci. 92:3026-3034.

Ziegler-Heitbrock, H. W. 1995. Molecular mechanism in tolerance to lipopolysaccharide. J. Inflamm. 45:13-26. 